\title{
Pursuing a Curative Approach in Multiple Myeloma: A Review of New Therapeutic Strategies
}

\author{
Mattia D'Agostino ${ }^{\dagger}$, Luca Bertamini ${ }^{\dagger}$, Stefania Oliva, Mario Boccadoro and Francesca Gay *(D) \\ Myeloma Unit, Division of Hematology, University of Torino, Azienda Ospedaliero-Universitaria Città della \\ Salute e della Scienza di Torino, 10126 Torino, Italy; mattiadagostino89@gmail.com (M.D.); \\ luca.bertamini92@gmail.com (L.B.); stefania.olivamolinet@gmail.com (S.O.); mario.boccadoro@unito.it (M.B.) \\ * Correspondence: fgay@cittadellasalute.to.it \\ † These authors contributed equally to this work and share the first authorship. \\ Received: 19 November 2019; Accepted: 9 December 2019; Published: 13 December 2019

\begin{abstract}
Multiple myeloma (MM) is still considered an incurable hematologic cancer and, in the last decades, the treatment goal has been to obtain a long-lasting disease control. However, the recent availability of new effective drugs has led to unprecedented high-quality responses and prolonged progression-free survival and overall survival. The improvement of response rates has prompted the development of new, very sensitive methods to measure residual disease, even when monoclonal components become undetectable in patients' serum and urine. Several scientific efforts have been made to develop reliable and validated techniques to measure minimal residual disease (MRD), both within and outside the bone marrow. With the newest multidrug combinations, a good proportion of MM patients can achieve MRD negativity. Long-lasting MRD negativity may prove to be a marker of "operational cure", although the follow-up of the currently ongoing studies is still too short to draw conclusions. In this article, we focus on results obtained with new-generation multidrug combinations in the treatment of high-risk smoldering MM and newly diagnosed MM, including the potential role of MRD and MRD-driven treatment strategies in clinical trials, in order to optimize and individualize treatment.
\end{abstract}

Keywords: multiple myeloma (MM); newly diagnosed; smoldering; minimal residual disease (MRD); high risk; autologous stem-cell transplantation (ASCT)

\section{Introduction}

Multiple Myeloma (MM) is a hematologic malignancy caused by the outgrowth of monoclonal plasma cells that leads to end-organ damage [1]. In 2018, MM accounted for $1.2 \%$ of all cancer diagnoses and $1.6 \%$ of all cancer deaths in Europe [2]. The median overall survival (OS) of newly diagnosed (ND) MM patients improved from 3.9 years for patients diagnosed between 2004 and 2007 to 6.3 years for those diagnosed between 2008 and 2012 to a median OS that is not yet reached in patients diagnosed after 2012 [3]. The introduction of new drug classes like proteasome inhibitors (PIs), immunomodulatory drugs (IMiDs), and, more recently, monoclonal antibodies (mAbs) has been the main determinant of the observed OS improvement, together with an improved supportive care. Nevertheless, the main cause of death in MM patients is still the development of drug-resistant disease [4]. Although obtaining deep responses is a universally recognized predictive factor of good outcome [5], long-term disease control, rather than disease eradication, is still the aim of MM treatment in current clinical practice, since the available data show that even patients achieving minimal residual disease (MRD) negativity relapse. This confirms the so-far incurable nature of MM. Recent data, comparing the survival of young MM patients treated between 2005 and 2015 to that of young patients affected by curable hematologic diseases (e.g., diffuse large B cell lymphoma (DLBCL) and Hodgkin 
Lymphoma (HL)) [6] and to that of the general population showed that MM patients have a 20-fold excess mortality compared to the general population, while DLBCL and HL have a non-significant excess mortality [6].

However, more recent results from clinical trials exploring novel three-drug and four-drug combinations showed unprecedented rates of prolonged and deep responses [7-11], with acceptable safety profiles even in elderly patients, thus increasing the likelihood not only to achieve disease control, but potentially cure, at least in a subset of patients. To design a potentially curative strategy, we have to focus on the first stages of the disease (smoldering MM (SMM), newly diagnosed MM $(\mathrm{NDMM})$ ), when the patient is treatment-naïve and disease genomic complexity is lower, as compared to the advanced relapsed/refractory setting.

In this review, we provide a summary of the new techniques used to detect residual disease at high sensitivity and of the results obtained in SMM and NDMM with new-generation combinations. We also explore how we can exploit these data in the future, towards a potential cure of MM.

\section{Evolution of Response Criteria and MRD Techniques}

To enable disease eradication strategies, it is mandatory to have sensitive methods to detect small amounts of residual disease after treatment. MM response criteria evolved together with therapies. While before the introduction of novel agents, the rates of complete remission (CR) were very low $(2 \%$ after 3 cycles of vincristine-doxorubicin-dexamethasone [12]), with novel combinations CR can now be obtained in $>60 \%$ of patients [9]. Conventionally, MM response is evaluated measuring M-protein levels in the blood and urine, but it is now clear that even when M-protein disappears, residual disease can still be present [13]. The Spanish group showed that, among patients with a conventionally defined $\mathrm{CR}$, there was a significant difference in outcome between MRD-negative and MRD-positive patients (median progression-free survival (PFS) 63 vs. 27 months, $p<0.001$; median OS not reached vs. 59 months, $p<0.001)$. Interestingly, the outcome of patients with MRD-positive CR was similar to the outcome of those achieving only a partial response (PR), thus suggesting that the advantage of reaching CR over PR relies on the MRD-negative status. Recently, response criteria have been updated, introducing a universal definition of MRD beyond CR (for a detailed definition of the updated response criteria, please refer to Kumar et al., 2016) [14-17].

Two techniques have been developed and validated to detect MRD into the bone marrow: multiparameter flow cytometry (MFC) and next-generation sequencing (NGS).

MFC detects and quantifies tumor plasma cells using cell surface and cytoplasmic markers. Neoplastic plasma cells are characterized by the aberrant expression of molecules like CD19, CD20, CD27, CD28, CD33, CD38, CD45, CD56, CD117, and surface membrane immunoglobulin [18]. The first attempts to detect MRD by MFC had a maximum sensitivity of $10^{-4}-10^{-5}$. The optimization of the MFC assay using two 8-color tubes, a bulk-lysis procedure, the acquisition of $\geq 10^{7}$ cells/sample, and the automatic plasma cell gating through a software tool led to reproducible results and enhanced the maximum sensitivity to $10^{-5}-10^{-6}$ (next-generation flow, NGF) [19,20]. Using NGF, Flores-Montero and colleagues demonstrated that $25 \%$ of patients who were classified as MRD-negative by second-generation MFC were indeed MRD-positive by NGF [20]. Moreover, NGF negativity predicted a significantly longer PFS than second-generation MFC negativity among CR patients $(p=0.02)[20]$.

NGS technique was mainly developed by Adaptive Biotechnologies (Seattle, WA, USA) by producing and validating ClonoSEQ®Assay, which has recently obtained, by the Food and Drug Administration (FDA), the authorization as standardized technique for the disease evaluation in MM patients [21]. In this test, DNA from the immunoglobulin genes is amplified and sequenced using baseline bone marrow sample and identical sequences detected in more than $5 \%$ of the reads are identified as clonal gene rearrangements. These rearrangements are then searched in follow-up samples to identify MRD [22,23]. NGS reaches maximum sensitivity up to $10^{-6}$ [21]. 
Ongoing clinical trials are evaluating NGS vs. NGF/MFC and their correlation [24], and will help understand if the two techniques can be considered equivalent in identifying MRD negativity at a specific cut-off. Each technique has its own advantages and drawbacks (Table 1).

Table 1. Comparison of next-generation sequencing (NGS) and next-generation flow (NGF) for the detection of minimal residual disease (MRD) in multiple myeloma.

\begin{tabular}{|c|c|c|}
\hline Characteristics & NGS & NGF \\
\hline Applicability & $\geq 90 \%$ & $\sim 100 \%$ \\
\hline Baseline sample & $\begin{array}{l}\text { Required for molecular marker } \\
\text { identification }\end{array}$ & Not required \\
\hline Number of cells & $1-2$ million cells/20 $\mu \mathrm{g}$ DNA & 10 million cells/tube \\
\hline Standardization & $\begin{array}{c}\text { Commercial companies } \\
\text { (e.g., Adaptive Biotechnologies) }\end{array}$ & Euro Flow consortium \\
\hline Sample processing & Fresh and/or stored samples & $\begin{array}{l}\text { Fresh sample required; processing } \\
\text { within } \leq 48 \mathrm{~h}\end{array}$ \\
\hline Sample quality control & Not feasible & $\begin{array}{l}\text { Possible to check by global bone } \\
\text { marrow cell analysis }\end{array}$ \\
\hline Quantitative & Yes & Yes \\
\hline Sensitivity & 1 in $10^{-5}-10^{-6}$ & 1 in $10^{-5}-10^{-6}$ \\
\hline Clonal evolution & Evaluable & Not evaluable \\
\hline Time required & 1 week & $3-4 \mathrm{~h}$ \\
\hline Support required & Bioinformatics support & $\begin{array}{l}\text { Expert flow cytometrist; } \\
\text { Automated software }\end{array}$ \\
\hline
\end{tabular}

The maximum sensitivity reached is a key point, especially in a curative perspective. Each log depletion in MRD levels predicts a 1-year median OS advantage (5.9 years at $10^{-2}-10^{-3}, 6.8$ years at $10^{-3}-10^{-4}$, and $\geq 7.5$ years at $\left.10^{-4}\right)$, suggesting that MRD levels at the highest sensitivity should be pursued [25]. Several reports suggested that once MRD-negative statuses are reached with a high sensitivity technique, patient prognoses are similar independently from the treatment that induced MRD negativity [26,27]. This observation also seems to apply to patients with adverse baseline prognostic factors (e.g., high-risk cytogenetics or elevated Revised International Staging System (R-ISS) stage), among whom MRD-negative patients at a sensitivity of $10^{-5}-10^{-6}[26,28]$, but not at a sensitivity of $10^{-4}$ [29], showed similar clinical outcomes compared to standard-risk patients. Nevertheless, reaching MRD negativity in high-risk patients may be harder [30], and intensive regimens are likely needed in this patient population $[8,9]$.

Even when evaluating MRD at a sensitivity of $10^{-6}$, there are still patients that can relapse. Relapses can also be caused by extramedullary disease [31]. Fluorodeoxyglucose (FDG) positron emission tomography/computed tomography (PET/CT) is currently considered the standard of care to assess residual disease outside the bone marrow [32,33]. The predictive role of post-treatment PET/CT has been demonstrated by different studies [34-36] and, in a head-to-head comparison [34], the normalization of PET/CT outperformed that of conventional magnetic resonance imaging after therapy for the prediction of PFS and OS. Recently, Zamagni et al. presented data on the standardization of PET/CT to define criteria for MRD negativity using the 5-point Deauville score. PET/CT imaging was a reliable predictor of outcomes regardless of treatment. The achievement of a Deauville score $\leq 3$ was the predictor of a longer time to disease progression and overall survival (OS) and, consequently, a potential standardized definition of PET/CT negativity [37]. 
MRD assessed by PET/CT and bone marrow techniques synergistically predict patient outcome, with the best PFS detected in patients who were MRD-negative both within and outside the bone marrow [38]; hence the definition of Imaging MRD negativity.

Both the NGS and the NGF-plus-Imaging approaches are needed for the response evaluation in the setting of a curative strategy. Nevertheless, from a practical perspective, it should be determined if all these techniques are necessary for all patients, or if it is possible to develop an algorithm to define how to proceed. To do this, we need to answer open questions such as: In which patients should we perform MRD (CR, stringent CR (sCR) very good partial response (VGPR))? What is the proportion of patients who are still PET-positive despite being MRD-negative in the bone marrow with a high cut-off level (e.g., $10^{-6}$ )? Vice versa, how many PET-positive patients are MRD-negative? Who are the patients that show discrepancies between the two evaluations? Ongoing studies including both BM and PET/CT evaluation at specific time points will help in drawing conclusions [37].

In the future, liquid biopsy approaches that use peripheral blood samples could potentially overcome the need to assess MRD both in the bone marrow and by imaging. However, these techniques are still at early developmental stages [39].

Besides achieving MRD negativity, a more important factor is maintaining it [40]: here comes the definition of "sustained MRD negativity" by the International Myeloma Working Group (IMWG), which uses the 1-year cut-off. An effort should be made to define the optimal duration of MRD negativity to reach an "operational cure"; this still remains an unanswered question, with a potentially great clinical relevance. For instance, in the chronic myeloid leukemia field, a sustained major molecular response lasting at least 2 years is usually required to be a candidate for treatment discontinuation [41], and longer deep molecular response durations prior to discontinuation are associated with the increasing probability of maintaining a major molecular response after discontinuation [42]. Little data are available in MM. Using MFC to monitor MM patients after induction and at different time points post-autologous stem-cell transplantation (ASCT), Gu and colleagues showed that, among patients achieving MRD negativity after the post-induction time point, MRD reappearance can happen 18-24 months after ASCT, thus suggesting that long-term confirmation of sustained MRD negativity may be necessary [43].

\section{Treatment of High-Risk SMM}

SMM [44] is an asymptomatic plasma cell neoplasm harboring a variable risk of progression to MM. Several scores have been proposed to assess SMM risk of progression to symptomatic MM (Table 2) $[45,46]$. 
Table 2. Smoldering multiple myeloma: risk stratification systems.

\begin{tabular}{|c|c|c|c|c|c|c|c|c|c|}
\hline \multirow{2}{*}{$\begin{array}{c}\text { Stratification } \\
\text { System }\end{array}$} & \multirow{2}{*}{$N$} & \multicolumn{2}{|c|}{ Low Risk } & \multicolumn{4}{|c|}{ Intermediate Risk } & \multicolumn{2}{|c|}{ High Risk } \\
\hline & & Criteria & $\begin{array}{c}\text { TTP } \\
\text { (Median) }\end{array}$ & \multicolumn{2}{|c|}{ Criteria } & \multicolumn{2}{|c|}{ TTP (Median) } & Criteria & $\begin{array}{c}\text { TTP } \\
\text { (Median) }\end{array}$ \\
\hline $\begin{array}{c}\text { Mayo Clinic } \\
{[47]}\end{array}$ & 273 & $\begin{array}{lc}- & \text { M-protein }<3 \\
\text { g/dL } \\
\text { plus } \\
-\quad \text { BMPCs }<10 \% \\
\end{array}$ & 19 years & \multicolumn{2}{|c|}{ 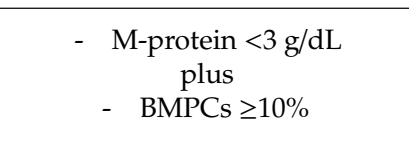 } & \multicolumn{2}{|c|}{8 years } & $\begin{array}{c}\text { - } \quad \text { M-protein } \geq 3 \\
\text { g/dL } \\
\text { plus } \\
\text { - } \quad \text { BMPCs } \geq 10 \%\end{array}$ & 2 years \\
\hline $\begin{array}{c}\text { PETHEMA } \\
{[48]}\end{array}$ & 89 & $\begin{array}{l}\text { - } \\
\text { Aberrant PCs by } \\
\text { MFC }<95 \% \\
\text { - } \quad \text { Immunoparesis }\end{array}$ & NR & \multicolumn{2}{|c|}{$\begin{array}{c}\text { - } \quad \text { Aberrant PCs by MFC } \geq 95 \% \\
\text { OR } \\
\text { - Immunoparesis }\end{array}$} & \multicolumn{2}{|c|}{6 years } & $\begin{array}{c}\text { - } \quad \text { Aberrant PCs by } \\
\text { MFC } \geq 95 \% \\
\text { AND } \\
\text { - } \quad \text { Immunoparesis }\end{array}$ & 1.9 years \\
\hline \multirow[t]{3}{*}{$\begin{array}{c}\text { Mayo } \\
\text { 2/20/20 [45] }\end{array}$} & \multirow[t]{2}{*}{421} & $\begin{array}{c}\text { None of the risk } \\
\text { factors: } \\
\text { - } \quad \text { M-protein }>2 \mathrm{~g} / \mathrm{dL} \\
-\quad \text { BMPCs }>20 \% \\
-\quad \text { FLCr }>20\end{array}$ & 9.1 years & $\begin{array}{r}\text { One ri } \\
-\quad \text { M-pro } \\
-\quad \text { BMI } \\
-\quad \text { FL }\end{array}$ & $\begin{array}{l}\text { factor: } \\
>2 \mathrm{~g} / \mathrm{dL} \\
>20 \% \\
>20\end{array}$ & 5.6 & & $\begin{array}{c}\geq 2 \text { risk factors: } \\
\text { - } \quad \text { M-protein }>2 \mathrm{~g} / \mathrm{dL} \\
-\quad \text { BMPCs }>20 \% \\
-\quad \text { FLCr }>20\end{array}$ & 2.4 years \\
\hline & & \multicolumn{2}{|c|}{$\begin{array}{ll}\text { Low Risk } \\
\end{array}$} & \multicolumn{2}{|c|}{ Intermediate Low } & \multicolumn{2}{|c|}{ Intermediate High } & \multicolumn{2}{|c|}{ High Risk } \\
\hline & $N$ & Criteria & $\begin{array}{c}\text { 2-year } \\
\text { progression } \\
\text { risk }\end{array}$ & Criteria & $\begin{array}{c}\text { 2-year } \\
\text { progression } \\
\text { risk }\end{array}$ & Criteria & $\begin{array}{c}2-y e a r \\
\text { progression } \\
\text { risk }\end{array}$ & Criteria & $\begin{array}{c}\text { 2-year } \\
\text { progression } \\
\text { risk }\end{array}$ \\
\hline $\begin{array}{c}2 / 20 / 20+\text { CA } \\
\text { by FISH * } \\
\text { [49] }\end{array}$ & 2004 & $\begin{array}{c}\text { None of the risk } \\
\text { factors: } \\
\text { - } \quad \text { M-protein }>2 \mathrm{~g} / \mathrm{dL} \\
-\quad \text { FLCr }>20 \\
\text { - } \quad \text { BMPCs }>20 \% \\
\text { Presence of any of } \\
\text { the CA } *\end{array}$ & $8 \%$ & $\begin{array}{c}1 \text { risk factor: } \\
-\quad \text { M-protein } \\
>2 \mathrm{~g} / \mathrm{dL} \\
-\quad \text { FLCr }>20 \\
-\quad \text { BMPCs } \\
>20 \% \\
\text { Presence of } \\
\text { any of the CA } \\
*\end{array}$ & $21 \%$ & $\begin{array}{c}2 \text { risk factors: } \\
-\quad \text { M-protein } \\
>2 \mathrm{~g} / \mathrm{dL} \\
-\quad \mathrm{FLCr}>20 \\
-\quad \text { BMPCs } \\
>20 \% \\
\text { Presence of } \\
\text { any of the CA } \\
*\end{array}$ & $37 \%$ & $\begin{array}{c}\geq 3 \text { risk factors: } \\
-\quad \text { M-protein }>2 \mathrm{~g} / \mathrm{dL} \\
-\quad \mathrm{FLCr}>20 \\
-\quad \text { BMPCs }>20 \% \\
\text { Presence of any of } \\
\text { the CA } *\end{array}$ & $59 \%$ \\
\hline
\end{tabular}

${ }^{*}$ High-risk chromosomal abnormalities: $\mathrm{t}(4,14), \mathrm{t}(14,16), 1 \mathrm{q}$ gain, or del13. $\mathrm{N}$, number; M-protein, myeloma protein; BMPCs, bone marrow plasma cells; CA, chromosomal abnormalities; FLCr, free light chain ratio; MFC, multiparameter flow cytometry; NR, not reached; PCs, plasma cells; TTP, time to progression; FISH, fluorescence in situ hybridization. 
The 2/20/20 model was the most recently proposed; its name comes from the resulting cut-offs of M-protein, bone marrow plasma cells (BMPC), and free light chains (FLC). M-protein $>2 \mathrm{~g} / \mathrm{dL}$ (hazard ratio (HR) 1.56, $p=0.01$; BMPC $\%>20 \%$ (HR 2.28, $p<0.0001$ ), and FLC ratio (FLCr) $>20$ (HR 2.13, $p<0.0001)$ ) independently predicted shorter time to progression (TTP) in multivariate analysis. Three risk groups were identified: Low risk (none of the risk factors), intermediate risk (1 risk factor), and high risk ( $\geq 2$ risk factors), with a median TTP of 110, 68, and 29 months, respectively $(p<0.0001)$ [45]. The high-risk group consisted of $36 \%$ of the analyzed cohort of SMM.

A retrospective multicenter study by the IMWG validated the 2/20/20 model; furthermore, incorporating the cytogenetic abnormalities detected by fluorescence in situ hybridization (FISH; presence vs. absence of $\mathrm{t}(4,14), \mathrm{t}(14,16), 1 \mathrm{q}$ gain, and/or del13), they identified four risk categories with a 2-year progression risk of 3.7\% (low risk), 25\% (low-intermediate), $49 \%$ (intermediate-high), and $72 \%$ (high) [49].

The current standard of care for SMM is periodical monitoring, with a suggested frequency based on patient risk to identify the possible evolution to symptomatic MM in due time and avoid severe organ damage. While this strategy suits well low-risk SMM patients who are unlikely to progress to MM, it may be questionable in high-risk SMM. In this setting, open questions are: (1) Can these patients benefit from an early therapy aiming at delaying the very likely evolution to MM? (2) Is there a possibility that early treatment may actually cure the disease? The latter hypothesis is based upon the very good outcome observed in patients with symptomatic MM and good prognosis [50], as well as upon a lower genomic complexity during the early phases of the disease that, together with a lower tumor burden, might suggest a higher possibility of cure [51]. Moreover, better treatment feasibility is expected in asymptomatic patients in good conditions. This rationale led to the design of clinical trials for the treatment of high-risk SMM (Table 3). 
Table 3. Smoldering multiple myeloma: Selected clinical trials.

\begin{tabular}{|c|c|c|c|c|c|c|c|}
\hline Protocol & Phase & & Treatment & Pts & Response & TTP/PFS/OS & Toxicity ( $\geq$ G3) \\
\hline $\begin{array}{l}\text { NCT00480363 } \\
\text { QuiRedex [52] }\end{array}$ & Phase III & Rd vs. observation & $\begin{array}{c}\text { Induction: } 28 \text {-day cycle } \\
\text { (cycles 1-9) lenalidomide } 25 \\
\text { mg p.o. days (D) } 1-21+\text { dex } \\
20 \text { mg p.o. D1-4, 12-15 } \\
\text { Maintenance: (cycles } 1-24 \text { ) } \\
\text { 28-day cycle } \\
\text { Lenalidomide } 10 \text { mg D1-21 } \\
\text { vs. } \\
\text { Observation }\end{array}$ & 119 & $\begin{array}{c}\text { FU } 73 \text { months } \\
\text { Best response } 26 \% \\
\text { CR after } \\
\text { maintenance }\end{array}$ & $\begin{array}{c}\text { Median TTP NR (HR } \\
0.24) \\
\text { 3-year PFS 77\% } \\
\text { 3-, 5-year OS 94\%, 88\% } \\
\text { (HR 0.43) } \\
\text { vs. } \\
\text { median TTP 23 months } \\
(p<0.001) \\
\text { 3-year PFS 30\% }(p< \\
0.001) \\
\text { 3-, 5-year OS 80\%, 71\%, } \\
(p=0.03)\end{array}$ & $\begin{array}{c}\text { Neutropenia } 5 \% \\
\text { Thrombocytopenia } 2 \% \\
\text { Anemia } 2 \% \\
\text { Infection 6\% } \\
\text { Asthenia 6\% } \\
\text { Skin rash 3\% } \\
\text { vs. } \\
\text { none }\end{array}$ \\
\hline $\begin{array}{c}\text { NCT01572480 } \\
120107 \text { [53] }\end{array}$ & Phase II & $\begin{array}{l}\text { KRd induction } \\
\text { Rd maintenance }\end{array}$ & $\begin{array}{c}\text { Induction: 28-day cycle } \\
\text { (cycles } 1-8 \text { ) carfilzomib } \\
20 / 36 \mathrm{mg} / \mathrm{m}^{2} \text { iv D1, 2, 8, }, \\
15,16+\text { lenalidomide } 25 \mathrm{mg} \\
\text { p.o. D } 1-21+\text { dex } 20 \mathrm{mg} \\
\text { (cycles } 1-4 \text { ) and } 10 \text { (cycles } \\
\text { 5-8) p.o. or iv D1, 2, 8, 9, 15, } \\
16 \\
\text { Maintenance (cycles 1-24): } \\
\text { 28-day cycle } \\
\text { lenalidomide } 25 \mathrm{mg} \text { D1-21 }\end{array}$ & 12 & $\begin{array}{c}\text { CR } 100 \% . \text { MRD } \\
\text { neg }\left(\mathrm{MFC} 10^{-5}\right) \\
92 \%\end{array}$ & $\begin{array}{c}\text { No progression to MM } \\
\text { 3-, 4-year PFS 94\%, } 70.6 \% \\
\text { 3-, 4- year OS: } 100 \%\end{array}$ & $\begin{array}{c}\text { Hematologic: } \\
\text { Lymphopenia } 39 \% \\
\text { Neutropenia } 28 \% \\
\text { Anemia } 22 \% \\
\text { Thrombocytopenia } 11 \% \\
\text { Non-hematologic: } \\
\text { Diarrhea } 17 \% \\
\text { Lung infection } 17 \% \\
\text { Hypophosphatemia } 11 \% \\
1 \text { case of CHF }\end{array}$ \\
\hline $\begin{array}{c}\text { NCT02415413 } \\
\text { GEM-CESAR } \\
\text { [54] }\end{array}$ & Phase II & $\begin{array}{l}\text { KRd induction } \\
\text { ASCT } \\
\text { KRd consolidation } \\
\text { Rd maintenance }\end{array}$ & $\begin{array}{c}\text { Induction: 28-day cycle } \\
\text { (cycles 1-6): carfilzomib } \\
20 / 36 \mathrm{mg} / \mathrm{m}^{2} \text { iv D1, 2, 8, 9, } \\
\text { 15, } 16+\text { lenalidomide } 25 \mathrm{mg} \\
\text { p.o. D1-21 + dex } 40 \mathrm{mg} \mathrm{D1} \\
8,15,22 \\
\text { ASCT melphalan } 200 \mathrm{mg} / \mathrm{m}^{2} \\
\text { Consolidation: KRd } 2 \text { cycles } \\
\text { Maintenance: } 28 \text {-day cycle } \\
\text { lenalidomide } 10 \text { mg days } \\
\text { 1-21 + } 20 \text { mg days } 1,8,15, \\
22 \text { for } 2 \text { years }\end{array}$ & 90 & $\begin{array}{c}\text { ORR: } 100 \% . \geq C R: \\
70 \% \\
\text { MRD (NGF) } 57 \%\end{array}$ & 30 months PFS 98\% & $\begin{array}{c}\text { Induction (G3-4): } \\
\text { Neutropenia 6\% } \\
\text { Thrombocytopenia } 11 \% \\
\text { Infections } 18 \% \\
\text { Consolidation: Ongoing }\end{array}$ \\
\hline
\end{tabular}


Table 3. Cont.

\begin{tabular}{|c|c|c|c|c|c|c|c|}
\hline Protocol & Phase & & Treatment & Pts & Response & TTP/PFS/OS & Toxicity ( $\geq$ G3) \\
\hline $\begin{array}{c}\text { NCT03673826 } \\
\text { HO147SMM }\end{array}$ & Phase II & $\begin{array}{c}\text { KRd vs. Rd } \\
\text { Rd maintenance }\end{array}$ & $\begin{array}{c}\text { Induction: } \\
\text { (cycles 1-9) carfilzomib } \\
\text { 20/36 mg/m }{ }^{2} \text { iv D1, 2, 8, } 9 \\
\text { 15, 16, lenalidomide 25 mg } \\
\text { p.o. D1-21, dexamethasone } \\
20 \text { mg p.o. (cycles 1-4) and } \\
10 \text { mg p.o. (cycles 5-9) D1, } \\
\text { 8, 15, } 22 \\
\text { vs. } \\
\text { (cycles 1-9) lenalidomide } 25 \\
\text { mg p.o D1-21, } \\
\text { dexamethasone } 20 \text { mg p.o. } \\
\text { (cycles 1-4) and } 10 \text { mg p.o. } \\
\text { (cycles 5-9) D1, 8, 15, 22 } \\
\text { Maintenance: (cycles 1-24) } \\
\text { lenalidomide 10 mg p.o. } \\
\text { days 1-21 of a 28-day cycle }\end{array}$ & 120 & NA & NA & NA \\
\hline $\begin{array}{l}\text { NCT03289299 } \\
\text { ASCENT }\end{array}$ & Phase II & $\begin{array}{c}\text { Dara KRd + Rd } \\
\text { maintenance }\end{array}$ & $\begin{array}{c}\text { Induction: 28-day cycle } \\
\text { (cycles 1-6) carfilzomib } \\
\text { 20/36 mg/m² iv D1, 2, 8, } 9 \text {, } \\
\text { 15, } 16 \text { + lenalidomide } 25 \mathrm{mg} \\
\text { p.o. D1-21 + dex } 40 \mathrm{mg} \text { D1, } \\
\text { 8, 15, 22, daratumumab 16 } \\
\text { mg/kg iv D1, 8, 15, and } 22 \text { of } \\
\text { cycles 1-2; D1 and } 15 \text { of } \\
\text { cycles 3-6; } \\
\text { Consolidation: } \\
6 \text { cycles, KR as in induction } \\
\text { + dex } 20 \text { mg p.o. D1, } 8,15, \\
22 \text { Daratumumab } 16 \mathrm{mg} / \mathrm{kg} \\
\text { iv D1 of cycles } 7-12 \\
\text { vs. } \\
\text { ASCT } \\
\text { Maintenance: } 12 \text { cycles, } \\
\text { lenalidomide } 10 \mathrm{mg} \text { p.o. } \\
\text { D1-21 } \\
\text { + daratumumab; } 16 \mathrm{mg} / \mathrm{kg} \\
\text { iv D1 of odd cycles for } \\
\text { cycles } 13-24\end{array}$ & 83 & NA & NA & NA \\
\hline
\end{tabular}


Table 3. Cont

\begin{tabular}{|c|c|c|c|c|c|c|c|}
\hline Protocol & Phase & & Treatment & Pts & Response & TTP/PFS/OS & Toxicity ( $\geq$ G3) \\
\hline $\begin{array}{c}\text { NCT02697383 } \\
15-294[55]\end{array}$ & Phase I & $\begin{array}{c}\text { Ixazomib } \\
\text { dexamethasone }\end{array}$ & $\begin{array}{c}\text { 28-day cycle } \\
\text { (cycles } 1-12 \text { ) ixazomib } 4 \mathrm{mg} \\
\text { on } \mathrm{D} 1,8 \text {, and } 15 \text {, and } \\
\text { dexamethasone on days } 1,8, \\
15 \text {, and } 22 \text { (40 mg/week the } \\
\text { first } 4 \text { cycles, thereafter } 20 \\
\text { mg/week) }\end{array}$ & 14 & ORR $64 \%$ & $\begin{array}{l}64 \% \text { ORR (8 PR, and } 1 \\
\text { VGPR) no patient } \\
\text { progressed to MM }\end{array}$ & Lung infection $(14 \%)$ \\
\hline $\begin{array}{l}\text { NCT01441973 } \\
\text { CA204-011 [56] }\end{array}$ & Phase II & Elotuzumab & $\begin{array}{c}\text { (cycle 1) elotuzumab } 20 \\
\mathrm{mg} / \mathrm{kg} \text { iv D1, } 8 \text { then [cycle } \\
\text { 2-progressive disease] } \\
\text { Elotuzumab monthly q4 } \\
\text { week } \\
\text { vs. } \\
\text { (cycle } 1 \text { ) elotuzumab } 10 \\
\mathrm{mg} / \mathrm{kg} \text { iv D1, } 8,15,22 \\
\text { (cycle 2-progressive } \\
\text { disease) elotuzumab } \\
\text { monthly q2 week }\end{array}$ & 31 & $\begin{array}{c}\text { Both groups ORR } \\
10 \%\end{array}$ & $\begin{array}{c}\text { Both groups } \\
\text { 2-year PFS 69\% }\end{array}$ & $\begin{array}{c}\text { Upper respiratory tract } \\
\text { infection } 7 \% \\
\text { vs. } \\
\text { Fatigue } 6 \% \\
\text { Diarrhea } 6 \% \\
\text { Insomnia 6\% }\end{array}$ \\
\hline $\begin{array}{c}\text { NCT02279394 } \\
14-338[57]\end{array}$ & Phase II & $\begin{array}{l}\text { Elotuzumab Rd + } \\
\text { stem-cell } \\
\text { mobilization }+ \\
\text { maintenance }\end{array}$ & $\begin{array}{c}\text { Induction: 28-day cycle } \\
\text { (cycles 1-2) elotuzumab } 10 \\
\text { mg/kg iv D1, 8, 15, } 22+ \\
\text { lenalidomide } 25 \text { mg p.o. } \\
\text { D1-21 + dex } 40 \text { mg p.o. D1, } \\
8,15,22 \text { (cycles 3-8): } \\
\text { elotuzumab } 10 \mathrm{mg} / \mathrm{kg} \text { iv D1, } \\
15+\text { lenalidomide as in } \\
\text { cycles } 1-2+\text { dex } 40 \mathrm{mg} \text { p.o. } \\
\text { D1, 8, 15 } \\
\text { Maintenance: } 28 \text {-day cycle } \\
\text { (cycles 9-4) elotuzumab } 10 \\
\text { mg/kg iv D } \\
1+\text { lenalidomide as in } \\
\text { cycles } 1-2\end{array}$ & 50 & $\geq$ VGPR $43 \%$ & $\mathrm{NA}$ & $\begin{array}{c}\text { Hypophosphatemia } 34 \% \\
\text { Neutropenia } 26 \% \\
\text { Lymphopenia } 22 \%\end{array}$ \\
\hline
\end{tabular}


Table 3. Cont

\begin{tabular}{|c|c|c|c|c|c|c|c|}
\hline Protocol & Phase & & Treatment & Pts & Response & TTP/PFS/OS & Toxicity ( $\geq$ G3) \\
\hline $\begin{array}{c}\text { NCT02916771 } \\
16-313[58]\end{array}$ & Phase II & Ixazomib-Rd & $\begin{array}{c}\text { Induction: 28-day cycle } \\
\text { (cycles 1-9): ixazomib } 4 \mathrm{mg} \\
\text { p.o. D1, } 8,15+ \\
\text { lenalidomide } 25 \mathrm{mg} \\
\text { p.o. D1-21 + dex } 40 \mathrm{mg} \text { p.o. } \\
\text { D1, 8, 15, 22 } \\
\text { Maintenance: } 28 \text {-day cycle } \\
\text { (cycles 10-24): ixazomib } 4 \\
\text { mg p.o. D1, } 8 \\
15 \text { + lenalidomide } 25 \mathrm{mg} \\
\text { p.o. D1-21 }\end{array}$ & 26 & $\geq$ VGPR $53.8 \%$ & NA & $\begin{array}{c}\text { Hypophosphatemia 13\% } \\
\text { Lymphopenia } 13 \% \\
\text { Neutropenia } 8.7 \% \text { (G4 } \\
\text { Neutropenia in 1 pt) }\end{array}$ \\
\hline $\begin{array}{l}\text { NCT01484275 } \\
\text { CR100755 [59] }\end{array}$ & Phase II & $\begin{array}{l}\text { Siltuxumab vs. } \\
\text { placebo }\end{array}$ & $\begin{array}{c}\text { (cycle } 1 \text { - until progressive } \\
\text { disease): siltuximab } 15 \\
\mathrm{mg} / \mathrm{kg} \text { iv every } 4 \text { weeks } \\
\text { vs. } \\
\text { observation }\end{array}$ & 87 & NA & $\begin{array}{c}\text { 1-year PFS: } 84 \% \\
\text { Median PFS: NR } \\
\text { vs. } \\
\text { 1-year PFS: } 74.4 \% \\
\text { Median PFS: } 23.8 \text { months }\end{array}$ & $\begin{array}{l}\text { Infections ( } 5 \text { patients in } \\
\text { siltuximab group and } 6 \\
\text { patients in placebo group) } \\
\text { Urinary disorders (one } \\
\text { patient in the siltuximab } \\
\text { group and three patients in } \\
\text { the placebo group) }\end{array}$ \\
\hline $\begin{array}{c}\text { NCT02960555 } \\
\text { 2015-0148 }\end{array}$ & Phase II & Isatuximab & $\begin{array}{l}\text { (cycles 1-30): 28-day cycle } \\
\text { isatuximab iv D1, 8, 15, and } \\
22 \text { of cycle } 1, \text { on D1 and } 15 \\
\text { of cycles } 2-6 \text {, and on D1 of } \\
\text { subsequent courses }\end{array}$ & 61 & NA & NA & NA \\
\hline $\begin{array}{c}\text { NCT02316106, } \\
\text { CENTAURUS } \\
\text { [60] }\end{array}$ & Phase II & $\begin{array}{c}\text { Daratumumab iv } \\
\text { ( } 3 \text { arms, } 41 \\
\text { patients each) }\end{array}$ & $\begin{array}{c}\text { Daratumumab } 16 \mathrm{mg} / \mathrm{kg} \text { iv } \\
\text { in 8-week cycles } \\
\text { Long intensity:(cycle 1) } \\
\text { every } 1 \text { week; (cycle 2-3) } \\
\text { every other } \\
\text { week; (cycles 4-7) every } 4 \\
\text { weeks; (cycles 8-20) every } 8 \\
\text { weeks } \\
\text { Intermediate intensity: } \\
\text { (cycle 1) every } 1 \text { week and } \\
\text { (cycles 2-20) every } 8 \text { weeks } \\
\text { Short intensity: (cycle 1) } \\
\text { every week for } 8 \text { infusions }\end{array}$ & 123 & $\begin{array}{l}\geq \mathrm{CR} \text { rate } 7 \% \text { in } \\
\text { combined Long } \\
\text { and Int arms }\end{array}$ & $\begin{array}{c}\text { Long intensity } \\
\text { 24-month PFS 90\% } \\
\text { vs. } \\
\text { intermediate intensity } \\
\text { 24-month PFS } 82 \% \\
\text { vs. } \\
\text { short intensity 24-month } \\
\text { PFS } \\
75 \%\end{array}$ & $\begin{array}{c}\text { Long intensity serious } \\
\text { adverse events, } 32 \% \\
\geq \mathrm{G} 3 \mathrm{AE} 44 \% \\
\text { - } \quad \text { Hypertension } 7 \% \\
\text { - } \quad \text { Hyperglycemia } 2 \% \\
\text { vs. } \\
\text { intermediate intensity } \\
\text { serious adverse events } 15 \% \\
\geq \mathrm{G} 3 \mathrm{AE} 27 \% \\
\text { - } \quad \text { Hypertension } 5 \% \\
\text { - Hyperglycemia 5\% } \\
\text { vs. } \\
\text { short intensity } \\
\text { serious adverse events, 10\% } \\
\geq \mathrm{G3} \text { AE } 15 \% \\
\text { - } \quad \text { Hypertension } 3 \% \\
\text { - Hyperglycemia } 0 \%\end{array}$ \\
\hline
\end{tabular}


Table 3. Cont.

\begin{tabular}{|c|c|c|c|c|c|c|c|}
\hline Protocol & Phase & & Treatment & Pts & Response & TTP/PFS/OS & Toxicity $(\geq \mathrm{G} 3)$ \\
\hline $\begin{array}{l}\text { NCT03301220 } \\
\text { AQUILA [61] }\end{array}$ & Phase III & $\begin{array}{l}\text { Daratumumab sc } \\
\text { for } 3 \text { years vs. } \\
\text { observation }\end{array}$ & $\begin{array}{c}\text { Daratumumab sc injection } \\
\text { (daratumumab } 1800 \mathrm{mg}+ \\
\text { rHuPH20 }[2000 \mathrm{U} / \mathrm{mL}] \text { ) } \\
\text { once weekly for cycles } 1 \\
\text { and } 2 \text { (D1, 8, 15, and } 22 \text { of } \\
\text { each week), every } 2 \text { weeks } \\
\text { for cycles 3-6 (D1 and 15), } \\
\text { and thereafter every 4 } \\
\text { weeks (D1) until } 39 \text { cycles or } \\
\text { up to } 36 \text { months or PD } \\
\text { vs. } \\
\text { observation }\end{array}$ & 390 & NA & NA & NA \\
\hline $\begin{array}{c}\text { NCT01169337 } \\
\text { E3A06 [62] }\end{array}$ & Phase II-III & $\begin{array}{l}\text { R vs. observation } \\
\text { (median FU } 35 \\
\text { months) }\end{array}$ & $\begin{array}{l}\text { Lenalidomide } 25 \text { mg p.o. } \\
\text { D1-21 in } 28 \text { days cycle until } \\
\text { PD } \\
\text { vs. } \\
\text { observation }\end{array}$ & 180 & $\begin{array}{c}\text { Overall response } \\
47.7 \% \text { phase II } \\
48.9 \% \text { phase III }\end{array}$ & $\begin{array}{c}\text { PFS } 1 \text { year } \\
\text { (98\% vs. } 89 \%), \\
\text { PFS } 2 \text { years } \\
(93 \% \text { vs. } 76 \%) \\
\text { PFS } 3 \text { years } \\
(91 \% \text { vs. } 66 \%)\end{array}$ & $\begin{array}{c}\text { G3/4 non-hematologic } \\
\text { AEs } 28 \%: \\
\text { - Infections } 10 \% \\
\text { - Fatigue } 6.8 \% \\
\text { - Hypertension } 9 \% \\
\text { G4 hematologic AEs } \\
\text { 4.5\%, primarily } \\
\text { neutropenia }(n=4), \\
\text { cumulative incidence of } \\
\text { invasive SPMs } 11.4 \% \\
\text { (Len) and } 3.5 \% \\
\text { (observation). }\end{array}$ \\
\hline
\end{tabular}


In the phase III randomized QuiRedex study, 119 high-risk SMM patients [52] received lenalidomide-dexamethasone (Rd) vs. observation. After a median follow-up of 75 months, the median TTP was not reached in the Rd group $(n=57)$ vs. 23 months in the observation group $(n=62$, HR 0.24, $p<0.0001$ ). An advantage in OS in the Rd arm was also detected (HR 0.43, $p=0.024$ ). Interestingly, survival was similar in the two groups for patients who had previously received subsequent lines of therapy at the progression to active disease (HR 1.34, $p=0.50$ ). The Rd combination showed acceptable levels of toxicity: Grade $\geq 3$ adverse events (AEs) were infection (6\%), asthenia (6\%), neutropenia $(5 \%)$, and skin rash (3\%). During treatment, two patients treated with lenalidomide died of infection. A higher rate of second primary malignancies (SPMs) was detected in the Rd group (10\%) vs. the observation group ( $2 \%$ ). Of note, progression was defined by classical CRAB criteria (hyperCalcemia, Renal failure, Anemia, and Bone lesions) and advanced imaging techniques at screening were not performed, thus suggesting that the study also included patients who would currently be classified as having symptomatic MM.

The efficacy of lenalidomide was also shown in the phase II/III E3A06 study, in which lenalidomide was compared to observation in SMM [62]. After a median follow-up of 35 months in phase III of the trial, the overall response rate (ORR) was $50 \%$ in the $\mathrm{R}$ group and $0 \%$ in the observational group. One-year, 2-year, and 3-year PFS were respectively 98\%, 93\%, and 91\% in the R group, favorably comparing with respectively $89 \%, 76 \%$, and $66 \%$ in the observational arm (HR 0.28 , $p=0.002$ ). Among lenalidomide-treated patients, grade $3 / 4$ non-hematologic toxicities occurred in $28 \%$ of the phase III patients, with hypertension and infections being most common toxicities. However, no difference in scores regarding the quality of life was noted between the lenalidomide and the observational groups. In this trial, SPMs were detected in $11.4 \%$ of lenalidomide-treated patients vs. $3.4 \%$ of patients in the observational group.

In this setting, another attractive drug is the second-generation PI ixazomib, which is characterized by a convenient oral administration and shows good safety results. In a phase I study, ixazomib associated with dexamethasone showed good tolerability and high response rate (ORR 64\%, PR 57\%, and VGPR 14\%) [55]. A phase II study exploring the entirely oral triplet ixazomib-lenalidomide-dexamethasone confirmed the good tolerability profile and efficacy of this combination, with a $58 \%$ of $\geq$ VGPR (CR 19\%, VGPR 34\%) [58].

MAbs were also evaluated for the treatment of SMM. The anti-SLAMF7 elotuzumab as single agent showed a low response rate (ORR 10\%, minimal response (MR) 29\%), with a 2-year PFS of 69\%, while first data of the combination with Rd showed $a \geq$ VGPR rate of $43 \%[56,57]$.

The phase II CENTAURUS trial evaluated daratumumab alone in 123 patients with three different dose schedules and durations (long intense, intermediate, short intense; Table 3) [60]. At a median follow-up of 25.9 months, $\geq$ VGPR rates were higher in the long intense and intermediate arms compared to the short intense arm (29\%, 25\%, and 18\%, respectively). The 24-month PFS rates were $90 \%$, $82 \%$, and $75 \%$ in the three arms. Grade $\geq 3$ AEs occurred in $44 \%$ (long intense), $27 \%$ (intermediate), and $15 \%$ (short intense) of patients. The most frequent grade $3-4$ AEs were hypertension and hyperglycemia. The subcutaneous formulation of daratumumab is also being explored in a randomized phase III trial against active monitoring in this setting (NCT03301220). Another anti-CD38 mAb, isatuximab, is under evaluation (NCT02960555).

More intense regimens using three- or four-drug combinations \pm ASCT were used in the high-risk SMM setting, aiming at the eradication of MM.

In a small cohort of 12 high-risk SMM patients, Korde and colleagues demonstrated that carfilzomib-lenalidomide-dexamethasone (KRd) induced deep responses ( $\geq$ CR $100 \%$ ) and MRD negativity ( $92 \%$ by MFC); after a median follow-up of 15.9 months, none of the patients progressed to MM [53]. Interestingly, the same regimen administered in the NDMM setting produced a lower rate of deep responses ( $\geq \mathrm{CR} 56 \%$ ), suggesting that high-risk SMM patients can be more sensitive to treatment [53]. 
In the single-arm, phase II GEM-CESAR trial, patients received KRd as induction, ASCT, KRd as consolidation and maintenance therapy with Rd. After a median follow-up of 32 months (8-128), the 30-month PFS was 93\% and each phase of therapy was associated with increasing rates of MRD negativity evaluated by NGF (sensitivity $3 \times 10^{-6} ; 31 \%$ after induction, $56 \%$ after ASCT, $63 \%$ after consolidation). During induction, the most common $\mathrm{G} \geq 3$ AEs were infections (18\%), skin rash $(9 \%)$, neutropenia $(6 \%)$, and thrombocytopenia (11\%). Cardiac AEs were rare: 1 grade 1 atrial fibrillation, 1 cardiac failure secondary to respiratory infection, and 3 cases of hypertension during consolidation [54].

Another ongoing randomized phase II study (HO147SMM) is comparing KRd to Rd, but no data are available yet.

The addition of the anti-CD38 mAb daratumumab to KRd induction and consolidation is being evaluated in the ASCENT study (NCT03289299), which is now recruiting patients. A randomized comparison of daratumumab-Rd vs. Rd in the context of high-risk SMM is also ongoing (NCT03937635).

\section{Treatment of Symptomatic NDMM}

The first efforts aiming at a curative approach in NDMM were done by the University of Arkansas group in the 1990s, developing a program called Total Therapy (TT) using a series of non-cross-resistant induction regimens, 2 cycles of high-dose chemotherapy, followed by ASCT and maintenance treatment [63]. Toxicity concerns and the unavailability of novel agents hindered the success of this approach, although the long-term follow-up of treated patients (median 21 years) showed a plateau in the survival curves with an estimated cure rate of $9 \%$ based on PFS data and of $18 \%$ based on the duration of CR [64].

Currently, general treatment approaches in NDMM patients are tailored upon their eligibility for high-dose therapy (HDT) and ASCT [65].

\subsection{ASCT-Eligible Patients}

The current therapeutic approach includes sequential induction therapy and ASCT \pm consolidation, followed by maintenance. Induction is typically administered for $4-6$ cycles prior to ASCT [66]. The introduction of the PI bortezomib increased the response rate compared to classical chemotherapy [67], and is now a backbone of treatment. The addition of a third drug to the bortezomib-dexamethasone (Vd) combination (i.e., thalidomide [VTd], cyclophosphamide [VCd], lenalidomide [VRd], doxorubicin [PAD]) increased the depth of response [68]. In a head-to-head comparison, VTd was superior to VCd as induction prior to HDT-ASCT in terms of ORR ( $92 \% \mathrm{vs.}$ $83 \%$ ) and $\geq$ VGPR rate (66\% vs. 56\%) [69], demonstrating that even with first-generation novel agents, the combination of a PI and an IMiD was beneficial.

In phase III trials, VRd induction was tested in the PETHEMA and Intergroupe Francophone du Myélome (IFM) 2009 studies (Table 4). 
Table 4. Newly diagnosed multiple myeloma: selected clinical trials enrolling transplant-eligible patients.

\begin{tabular}{|c|c|c|c|c|c|c|c|}
\hline Protocol & Phase & & Treatment & Subjects & Response & TTP/PFS/OS & Toxicity ( $\geq$ G3) \\
\hline $\begin{array}{c}\text { NCT01206205 } \\
\text { IFM2008 [70] }\end{array}$ & Phase II & $\begin{array}{l}\text { VRd induction } \\
\text { Stem-cell } \\
\text { mobilization } \\
\text { ASCT } \\
\text { VRd } \\
\text { consolidation } \\
\text { R maintenance }\end{array}$ & 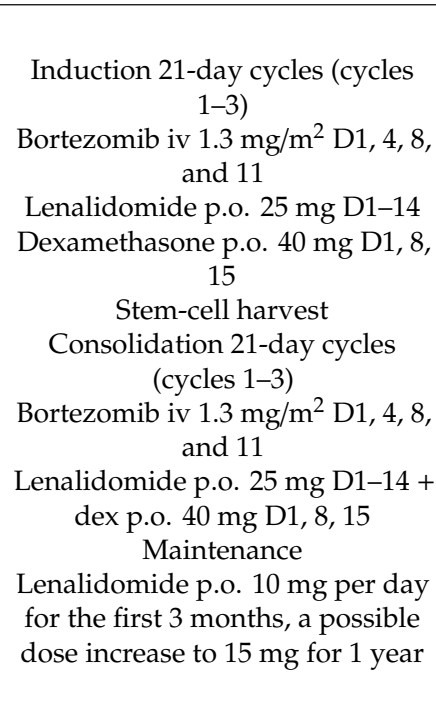 & 31 & $\begin{array}{c}\text { After induction } \\
58 \% \geq \text { VGPR } \\
23 \% \geq \text { CR } \\
16 \% \text { MRD neg MFC } \\
\left(10^{-4}-10^{-5}\right) \\
\text { After ASCT } \\
70 \% \geq \text { VGPR } \\
47 \% \geq \text { CR } \\
54 \% \text { MRD neg MFC } \\
\left(10^{-4}-10^{-5}\right) \\
\text { After consolidation } \\
87 \% \geq \text { VGPR } \\
50 \geq \text { CR } \\
58 \% \text { MRD neg MFC } \\
\left(10^{-4}-10^{-5}\right) \\
\text { Best response (after } \\
\text { maintenance) } \\
84 \% \geq \text { VGPR } \\
58 \% \geq \text { CR } \\
68 \% \text { MRD neg MFC } \\
\left(10^{-4}-10^{-5}\right)\end{array}$ & $\begin{array}{c}\text { Estimated 3-year } \\
\text { PFS 77\% and OS } \\
\text { 100\% (median } \\
\text { FU } 39 \text { months) }\end{array}$ & $\begin{array}{c}\text { Neutropenia } 65 \% \\
\text { Thrombocytopenia } \\
19 \% \\
\text { Anemia 3\% } \\
\text { Infections 6\% }\end{array}$ \\
\hline $\begin{array}{c}\text { NCT00507442 } \\
\text { EVOLUTION } \\
{[71]}\end{array}$ & $\begin{array}{c}\text { Phase II } \\
\text { randomized }\end{array}$ & $\begin{array}{c}\text { VRd }(n=42) \text { vs. } \\
\text { VRCd }(n=48) \\
\text { vs. } \\
\text { VCd }(n=33)\end{array}$ & $\begin{array}{c}\text { Induction 21-day cycles } \\
\text { (cycles 1-8) } \\
\text { Bortezomib } 1.3 \mathrm{mg} / \mathrm{m}^{2} \text {, days 1, 4, } \\
8,11 \\
\text { Dexamethasone } 40 \mathrm{mg}, \mathrm{D} 1,8,15 \\
\text { Cyclophosphamide } 500 \mathrm{mg} / \mathrm{m}^{2}, \\
\text { D1, } 8 \\
\text { Lenalidomide p.o., } 15 \mathrm{mg} \text { in } \\
\text { VRCd and } 25 \mathrm{mg} \text { in VRd D1-14 } \\
\text { Maintenance 6-week cycles (cycles } \\
\text { 1-4) Bortezomib } 1.3 \mathrm{mg} / \mathrm{m}^{2}, \mathrm{D} 1,8, \\
15,22 \\
\text { Stem-cell mobilization any time } \\
\text { after } 2 \text { cycles } \\
\text { ASCT any time after } 4 \text { cycles }\end{array}$ & 140 & $\begin{array}{c}\text { VRd best response } \\
61 \% \geq \text { VGPR } \\
21 \% \text { CR } \\
\text { VRCd best response } \\
54 \% \geq \text { VGPR } \\
21 \% \text { CR } \\
\text { VCd best response } \\
24 \% \geq \text { VGPR } \\
10 \% \text { CR }\end{array}$ & $\begin{array}{c}\text { 1-year PFS } \\
83 \% \text { VRd } \\
86 \% \text { VRCd } \\
93 \% \text { VCd } \\
100 \% \text { VCd-mod } \\
\text { 1-year OS } \\
\text { estimate } \\
92 \% \text { VRCd arm } \\
100 \% \text { for the } \\
\text { other three arms }\end{array}$ & $\begin{array}{c}\text { VRd } \\
\text { Neuropathy } 17 \% \\
\text { vs. } \\
\text { VRCd } \\
\text { Neuropathy } 13 \% \\
\text { vs. } \\
\text { VCd } \\
\text { Neuropathy } 9 \%\end{array}$ \\
\hline
\end{tabular}


Table 4. Cont

\begin{tabular}{|c|c|c|c|c|c|c|c|}
\hline Protocol & Phase & & Treatment & Subjects & Response & TTP/PFS/OS & Toxicity ( $\geq$ G3) \\
\hline $\begin{array}{c}\text { NCT01554852 } \\
\text { MyelomaXI } \\
{[72,73]}\end{array}$ & $\begin{array}{l}\text { Phase III } \\
\text { randomized }\end{array}$ & $\begin{array}{l}\text { Transplant } \\
\text { eligible: } \\
\text { CTd vs. CRd vs. } \\
\text { KCRd induction } \\
\quad \text { CVd } \\
\text { intensification vs. } \\
\text { no intensification } \\
\text { Mel200 ASCT } \\
\text { Lenalidomide } \\
\text { maintenance vs. } \\
\text { observation }\end{array}$ & 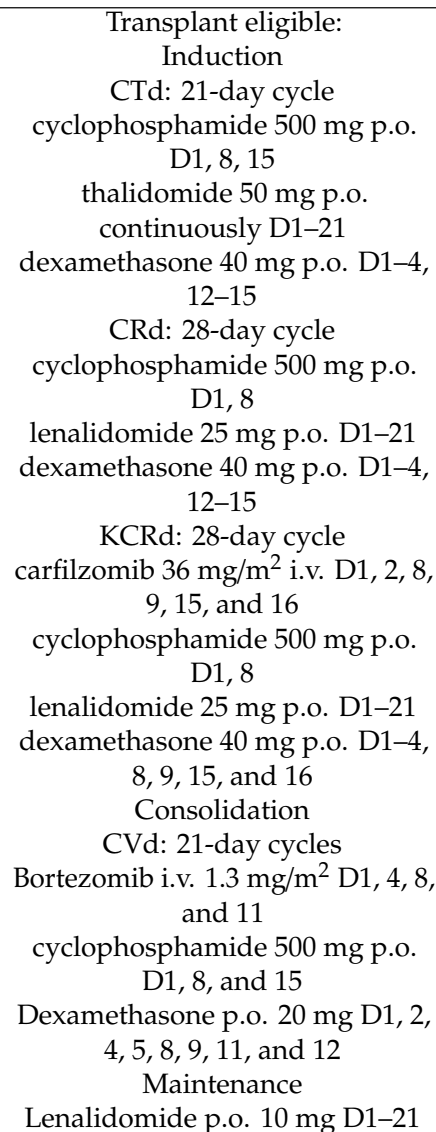 & 1056 & $\begin{array}{c}\text { Post-induction } \\
\text { CTd } \\
53 \% \geq \text { VGPR } \\
11 \% \text { MRD neg }(\mathrm{MFC} \\
\left.10^{-4}-10^{-5}\right) \\
\text { CRd } \\
65 \% \geq \text { VGPR } \\
21 \% \text { MRD neg } \\
\text { KCRd } \\
82 \% \geq \text { VGPR } \\
55 \% \text { MRD neg }\end{array}$ & $\begin{array}{c}\text { 3-year PFS } \\
50.3 \% \text { CTd/CRd } \\
64.5 \% \text { KCRd }\end{array}$ & $\begin{array}{c}\text { - Neutropenia } \\
12.8 \% \text { CTd } \\
22.3 \% \text { CRd } \\
16.4 \% \text { KCRd } \\
- \\
\text { Thrombocytopenia } \\
1.2 \% \text { CTd } \\
2.3 \% \text { CRd } \\
8.4 \% \text { KCRd }\end{array}$ \\
\hline
\end{tabular}


Table 4. Cont

\begin{tabular}{|c|c|c|c|c|c|c|c|}
\hline Protocol & Phase & & Treatment & Subjects & Response & TTP/PFS/OS & Toxicity ( $\geq$ G3) \\
\hline $\begin{array}{c}\text { NCT01191060 } \\
\text { IFM2009 [74] }\end{array}$ & Phase III & $\begin{array}{c}\text { VRd induction } \\
\text { arm } \\
\text { VRd } \\
\text { consolidation } \\
\text { arm } \\
\text { ASCT }\end{array}$ & $\begin{array}{r}\text { Induction: 21-day cycles (cycles } \\
\text { 1-3) Bortezomib i.v. } 1.3 \mathrm{mg} / \mathrm{m}^{2} \mathrm{D} 1 \text {, } \\
\text { 4, 8, and } 11 \\
\text { Lenalidomide p.o. } 25 \mathrm{mg} \mathrm{D1-14} \\
\text { Dexamethasone p.o. } 20 \mathrm{mg} \mathrm{D} 1,2 \text {, } \\
4,5,8,9,11 \text {, and } 12 \\
\text { Stem-cell mobilization with } \\
\text { cyclophosphamide and G-CSF } \\
\text { Consolidation (cycles 4-8) VRd } \\
\text { reduced dex } 10 \mathrm{mg} \text { (VRd-alone } \\
\text { group) } \\
\text { vs. } \\
\text { Melphalan } 200 \mathrm{mg} / \mathrm{m}^{2} \mathrm{ASCT}+2 \\
\text { cycles of } \\
\text { VRd reduced dex } 10 \mathrm{mg} \\
\text { (transplantation group) } \\
\text { Maintenance } \\
\text { Lenalidomide p.o. } 10 \mathrm{mg} \text { per day } \\
\text { for the first } 3 \text { months, a possible } \\
\text { dose increase to } 15 \mathrm{mg} \text { for } 1 \text { year }\end{array}$ & 700 & $\begin{array}{c}\text { VRd arm } \\
\text { After induction } \\
45 \% \geq \text { VGPR } \\
\text { After consolidation } \\
\geq 69 \% \text { VGPR } \\
\text { Best response (after } \\
\text { maintenance) } \\
77 \% \geq \text { VGPR } \\
48 \% \text { CR } \\
\text { of which } 65 \% \text { MRD neg } \\
\text { vs. } \\
\text { VRd-ASCT } \\
\text { After induction } \\
47 \% \geq \text { VGPR } \\
\text { After consolidation } \\
78 \% \geq \text { VGPR } \\
\text { Best response } \\
88 \% \geq \text { VGPR } \\
59 \% \text { CR } \\
\text { of which } 79 \% \text { MRD neg }\end{array}$ & $\begin{array}{c}\text { Median PFS } 50 \\
\text { vs. } 36 \text { months } \\
\text { OS } 4 \text { years } \\
81 \% \text { vs. } 82 \%\end{array}$ & $\begin{array}{c}\text { Neutropenia ( } 47 \% \\
\text { vs. } 92 \%) \\
\text { Gastrointestinal } \\
\text { disorders (7\% vs. } \\
28 \%) \\
\text { Infections ( } 9 \% \text { vs. } \\
20 \%)\end{array}$ \\
\hline $\begin{array}{l}\text { NCT01916252 } \\
\text { GEM2012 } \\
\text { MENOS65 [75] }\end{array}$ & Phase III & $\begin{array}{c}\text { VRd } 6 \text { cycles } \\
\text { Stem cell } \\
\text { mobilization } \\
\text { after } 3 \text { induction } \\
\text { cycles } \\
\text { Mel200-ASCT } \\
\text { vs. } \\
\text { BuMel-ASCT } \\
\text { VRd } 2 \text { cycles } \\
\text { post-transplant } \\
\text { consolidation }\end{array}$ & $\begin{array}{c}\text { Induction (cycles 1-6) } \\
\text { Bortezomib } 1.3 \mathrm{mg} / \mathrm{m}^{2} \mathrm{sc} \text { D1, 4, } \\
\text { 11 Lenalidomide } 25 \mathrm{mg} / \text { day D1-21 } \\
\text { Dexamethasone } 40 \mathrm{mg} \text { on D1-4 } \\
\text { and } 9-12 \text { at } 4 \text { weeks } \\
\text { ASCT } \\
\text { Melphalan } 200 \mathrm{mg} / \mathrm{m}^{2} \text { iv D } 2 \\
\mathrm{vs} . \\
\text { Busulfan } 9.6 \mathrm{mg} / \mathrm{kg}+\text { Melphalan } \\
140 \mathrm{mg} / \mathrm{m}^{2} \\
\text { Consolidation } \\
\text { (cycles } 7-8 \text { ) same schedule as } \\
\text { induction }\end{array}$ & 458 & $\begin{array}{c}\text { After induction } \\
29 \% \text { VGPR } \\
39 \% \text { CR } \\
28 \% \text { sCR } \\
34 \% \text { MRD-neg (by NGF) } \\
\text { After ASCT } \\
27 \% \text { VGPR } \\
49 \% \text { CR } \\
36 \% \text { sCR } \\
53 \% \text { MRD neg } \\
\text { After consolidation } \\
58 \% \text { MRD neg }\end{array}$ & NA & $\begin{array}{c}\text { Induction } \\
\text { Neutropenia 11\% } \\
\text { Thrombocytopenia } \\
6 \% \\
\text { Hepatic } 4 \% \\
\text { Skin 3\% } \\
\text { Neuropathy 1\% }\end{array}$ \\
\hline
\end{tabular}


Table 4. Cont

\begin{tabular}{|c|c|c|c|c|c|c|c|}
\hline Protocol & Phase & & Treatment & Subjects & Response & TTP/PFS/OS & Toxicity ( $\geq$ G3) \\
\hline $\begin{array}{c}\text { NCT01029054 } \\
\text { UMCC 2009.056 } \\
\text { [8] }\end{array}$ & $\begin{array}{c}\text { Phase I/II } \\
\text { Phase II } \\
\text { extended }\end{array}$ & $\begin{array}{c}\text { Phase I } \\
\text { KRd without } \\
\text { ASCT induction } \\
\text { and KRd } \\
\text { maintenance } \\
\text { Phase II } \\
\text { KRd induction } \\
\text { Mobilization } \\
\text { ASCT/Mel200 } \\
\text { KRd } \\
\text { consolidation } \\
\text { KRd } \\
\text { maintenance }\end{array}$ & 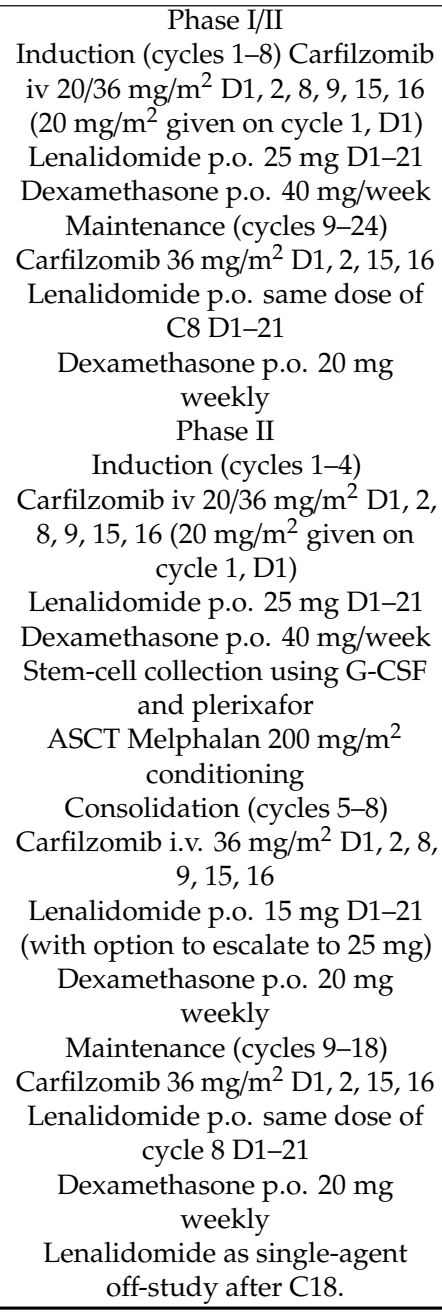 & $\begin{array}{l}53 \text { (phase I/II) } \\
76 \text { (phase II) }\end{array}$ & $\begin{array}{l} \\
\\
\\
\\
\text { Phase I/II } \\
\text { Post-induction (C8) } \\
55 \% \text { sCR } \\
\text { Phase II } \\
\text { Post-consolidation (C8) } \\
\text { 96\% } \geq \text { VGPR, 73\% CR } \\
69 \% \text { sCR. } \\
\text { Post-consolidation (C8) } \\
\text { 82\% MRD neg (MFC) (N = } \\
\text { 33) 66\% MRD neg (NGS) (N } \\
=29 \text { ) } \\
\text { Post-Maintenance (C18) } \\
\text { 90\% MRD neg (MFC) }(N= \\
\text { 20) 71\% MRD neg (NGS) (N } \\
\text { = 16) }\end{array}$ & $\begin{array}{c}\text { Phase I/II } \\
\text { 4- year PFS 63\% } \\
\text { 4-year OS 93\% } \\
\text { Phase II } \\
\text { 2-year PFS 97\% } \\
\text { and 2-year OS } \\
\text { 99\% } \\
\text { (median FU } 17 \\
\text { months) }\end{array}$ & $\begin{array}{c}\text { Phase II } \\
\text { Lymphopenia 28\% } \\
\text { Neutropenia 18\% } \\
\text { Infections } 8 \%\end{array}$ \\
\hline
\end{tabular}


Table 4. Cont.

\begin{tabular}{|c|c|c|c|c|c|c|c|}
\hline Protocol & Phase & & Treatment & Subjects & Response & TTP/PFS/OS & Toxicity ( $\geq$ G3) \\
\hline $\begin{array}{c}\text { NCT01402284 } \\
110221 \text { [53] }\end{array}$ & Phase II & $\begin{array}{l}\text { KRd induction } \\
\mathrm{R} \text { maintenance }\end{array}$ & $\begin{array}{c}\text { Induction (cycles } 1-8 \text { ) Carfilzomib } \\
\text { iv 20/36 mg/m², D1, 2, 8, 9, 15, } 16 \\
\text { Lenalidomide } 25 \mathrm{mg} \text { p.o. D1-21 } \\
\text { Dexamethasone } 20 \mathrm{mg} \text { (cycles } 1-4 \text { ) } \\
\text { and } 10 \text { (cycles 5-8) p.o. or iv D1, 2, } \\
8,9,15,16 \text { then } \\
\text { Maintenance (cycles } 1-24) \\
\text { lenalidomide } 25 \mathrm{mg} \text { D1-21 }\end{array}$ & 45 & $\begin{array}{c}62 \% \text { MRD neg (calculated } \\
\text { on NGS-evaluable NDMM } \\
\text { patients) }\end{array}$ & $\begin{array}{l}18 \text {-month PFS: } \\
100 \% \text { vs. } 84 \%\end{array}$ & $\begin{array}{c}\text { Lymphopenia } 34 \% \\
\text { Thrombocytopenia } \\
11 \% \\
\text { Neutropenia } 15 \% \\
\text { Anemia } 12 \% \\
\text { Infection } 6 \% \\
\text { Cardiac } 5 \% \\
\text { Vascular } 6 \%\end{array}$ \\
\hline $\begin{array}{c}\text { NCT02203643 } \\
\text { FORTE [9] }\end{array}$ & Phase II & $\begin{array}{c}\text { KCd-ASCT-KCd } \\
\text { (arm A), } \\
\text { KRd-ASCT- KRd } \\
\text { (arm B), } \\
\text { KRd } 12 \text { cycles } \\
\text { (arm C) }\end{array}$ & $\begin{array}{c}\text { Induction (cycles } 1-4 \text { ) Carfilzomib } \\
36 \mathrm{mg} / \mathrm{m}^{2} \mathrm{D} 1,2,8,9,15, \text { and } 16 \text { of } \\
\text { a 28-day cycle; lenalidomide p.o. } \\
25 \mathrm{mg} \text { D1-21 } \\
\text { Dexamethasone } 20 \mathrm{mg} \mathrm{D} 1,2,8,9 \text {, } \\
\text { 15, and } 16 \text { ) or } \\
\text { Cyclophosphamide } 300 \mathrm{mg} / \mathrm{m}^{2} \text { on } \\
\text { D1, 8, and } 15 \\
\text { Intensification } \\
\text { ASCT/mel200 or } 4 \text { KRd cyles } \\
\text { (cycles } 4-8 \text { ) } \\
\text { Consolidation (cycles } 8-12 \text { ) } \\
4 \text { cycles same as induction } \\
\text { Maintenance } \\
\text { KR vs. R (random) }\end{array}$ & 474 & $\begin{array}{c}\text { Pre-maintenance response } \\
\text { rates: } \geq \text { VGPR: } \\
76 \% \text { Arm A } \\
89 \% \text { Arm B } \\
87 \% \text { Arm C } \\
\text { sCR: } \\
32 \% \text { Arm A } \\
44 \% \text { Arm B } \\
43 \% \text { Arm C } \\
\text { Pre-maintenance MRD neg } \\
\text { MFC } \\
42 \% \text { Arm A } \\
58 \% \text { Arm B } \\
54 \% \text { Arm C }\end{array}$ & NA & $\begin{array}{c}\text { Dermatologic } \\
1-13 \% \\
\text { Neutropenia } \\
15-20 \% \\
\text { Thrombocytopenia } \\
8-15 \% \\
\text { Infections } 12-14 \% \\
\text { Increased liver } \\
\text { enzymes } 1-10 \% \\
\text { Hypertension } \\
3-8 \% \\
\text { Cardiac } 2-3 \%\end{array}$ \\
\hline $\begin{array}{l}\text { NCT02874742 } \\
\text { GRIFFIN [76] }\end{array}$ & Phase II & $\begin{array}{l}\text { Dara-VRd } \\
\text { induction } \\
\text { Mobilization } \\
\text { ASCT } \\
\text { Dara-VRd } \\
\text { consolidation } \\
\text { Dara-R } \\
\text { maintenance }\end{array}$ & $\begin{array}{c}\text { Induction (cycles 1-6) } \\
\text { Lenalidomide } 25 \mathrm{mg} \text { p.o. D1-14 } \\
\text { Bortezomib } 1.3 \mathrm{mg} / \mathrm{m}^{2} \mathrm{sc} \mathrm{D} 1,4,8, \\
\text { and } 11 \\
\text { Dexamethasone } 40 \mathrm{mg} \text { weekly } \\
\text { Daratumumab } 16 \mathrm{mg} / \mathrm{kg} \text { iv D1, } 8, \\
\text { and } 15 \text { of cycles } 1-4 \text { and on D1 of } \\
\text { cycles } 5-6 . \\
\text { Maintenance (C7-32) } \\
\text { lenalidomide } 10 \mathrm{mg} \text { p.o. daily (15 } \\
\text { mg beginning at cycle } 10 \text { if } \\
\text { tolerated) on D1-21 every } 28 \text { days } \\
\text { and Dara } 16 \mathrm{mg} / \mathrm{kg} \text { iv every } 56 \\
\text { days; } \\
\text { Maintenance lenalidomide may } \\
\text { be continued beyond C32 }\end{array}$ & $\begin{array}{c}207 \text { (safety run in } \\
16 \mathrm{pts} \text { ) }\end{array}$ & $\begin{array}{c}\text { Post-consolidation } \\
\text { (Dara-VRd) } \\
91 \% \geq \text { VGPR } \\
52 \% \geq \text { CR of which } \\
59 \% \text { MRD neg } \\
\text { vs. } \\
\text { (VRd) } \\
73 \% \geq \text { VGPR } \\
42 \% \geq \text { CR of which } \\
24 \% \text { MRD neg }\end{array}$ & $\begin{array}{l}\text { NA (FU } 13.5 \\
\text { months) }\end{array}$ & $\begin{array}{l}\qquad>10 \% \\
\text { Cytopenia similar } \\
\text { in two arms } \\
40 \% \text { of Dara } \\
\text { infusion-related } \\
\text { reaction (mainly } \\
\text { G1-2) }\end{array}$ \\
\hline
\end{tabular}


Table 4. Cont.

\begin{tabular}{|c|c|c|c|c|c|c|c|}
\hline Protocol & Phase & & Treatment & Subjects & Response & TTP/PFS/OS & Toxicity ( $\geq$ G3) \\
\hline $\begin{array}{c}\text { NCT02541383 } \\
\text { CASSIOPEIA } \\
\text { [77] }\end{array}$ & Phase III & $\begin{array}{l}\text { Dara-VTd-ASCT- } \\
\text { Dara-VTd vs. } \\
\text { VTd-ASCT-VTd } \\
\text { Maintenance } \\
\text { Daratumumab } \\
\text { vs. observation }\end{array}$ & $\begin{array}{c}\text { Induction (cycles 1-4) and } \\
\text { consolidation (cycle } 5-6) \\
\text { Bortezomib } 1.3 \mathrm{mg} / \mathrm{m}^{2} \mathrm{D} 1,4,8,11 \\
\text { Thalidomide } 100 \mathrm{mg} \text { daily p.o. in } \\
\text { all cycles } \\
\text { Dexamethasone } 40 \mathrm{mg} \text { p.o. or iv } \\
\mathrm{D} 1,2,8,9,15,16,22, \text { and } 23 \text { of } \\
\text { induction cycles } 1 \text { and } 2 \text { and D } 1 \\
\text { and } 2 \text { of induction cycles } 3 \text { and } 4 \\
\text { and } 20 \mathrm{mg} \text { on } \mathrm{D} 8,9,15,16 \text { of } \\
\text { induction cycles } 3-4 \text { and } \mathrm{D} 1,2,8, \\
\text { 9, } 15 \text {, and } 16 \text { of both consolidation } \\
\text { cycles. } \\
\text { Daratumumab iv } 16 \mathrm{mg} / \mathrm{kg} \text { once } \\
\text { weekly in induction cycles } 1 \text { and } 2 \\
\text { and once every } 2 \text { weeks during } \\
\text { induction cycles } 3 \text { and } 4 \text { and } \\
\text { consolidation } \\
\text { Stem-cell mobilization with } \\
\text { cyclophosphamide ( } 3 \mathrm{~g} / \mathrm{m}^{2} \text { ) } \\
\text { ASCT } \\
\text { Mel200 mg/m }{ }^{2} \text { iv conditioning } \\
\text { Maintenance } \\
\text { Daratumumab (16 mg/kg) every } 8 \\
\text { weeks until disease progression or } \\
\text { for a maximum of } 2 \text { years } \\
\text { vs. } \\
\text { observation }\end{array}$ & 1085 & $\begin{array}{c}\text { Post-consolidation } \\
\text { (Dara-VTd) } \\
83 \% \geq \text { VGPR } \\
10 \% \text { CR } \\
28.9 \% \text { sCR } \\
64 \% \text { MRD neg (MFC) } \\
39 \% \text { MRD neg (NGS) } \\
\text { vs. } \\
\text { (VTd) } \\
78 \% \geq \text { VGPR } \\
6 \% \text { CR } \\
20.3 \% \text { sCR } \\
44 \% \text { MRD neg (MFC) } \\
23 \% \text { MRD neg (NGS) }\end{array}$ & $\begin{array}{c}\text { Probability: } 18 \\
\text { months PFS } \\
\text { (Dara-VTd) } 93 \% \\
\text { vs. } \\
\text { (VTd) } \\
85 \% \\
\text { OS NR }\end{array}$ & $\begin{array}{c}\text { Neutropenia } 28 \% \\
\text { vs. } 15 \% \\
\text { Thrombocytopenia } \\
11 \text { vs. } 7 \% \\
\text { Neuropathy } 9 \% \text { vs. } \\
9 \% \\
\text { GIT } 16 \% \\
\text { Reaction infusion } \\
4 \% \text { in Dara-VTd }\end{array}$ \\
\hline $\begin{array}{l}\text { NCT01998971 } \\
\text { MMY1001 [11] }\end{array}$ & Phase Ib & Dara-KRd & $\begin{array}{c}\text { Daratumumab } 16 \mathrm{mg} / \mathrm{kg} \text { QW for } \\
\text { cycles } 1-2, \text { Q2W for cycles 3-6, } \\
\text { and Q4W (1st dose of Dara split } \\
\text { over } 2 \text { days) } \\
\text { Carfilzomib } 20 / 36 \mathrm{mg} / \mathrm{m}^{2} \mathrm{iv} \\
\text { weekly D1, } 8 \text { and } 15 \text { of each } \\
\text { 28-day cycle }\left(20 \mathrm{mg} / \mathrm{m}^{2} \text { on cycle } 1 \text {, }\right. \\
\text { D1) for } \leq 13 \text { cycles or elective } \\
\text { discontinuation for ASCT } \\
\text { Lenalidomide p.o. } 25 \mathrm{mg} \text { D1-21 } \\
\text { and Dexamethasone } 20-40 \mathrm{mg} \text { per } \\
\text { week }\end{array}$ & 22 & $\begin{array}{c}\text { Best response } \\
\text { 33\% VGPR } \\
14 \% \text { CR } \\
43 \% \text { sCR }\end{array}$ & 1-year PFS 95\% & $\begin{array}{c}\text { Lymphopenia } 50 \% \\
\text { Neutropenia } 23 \% \\
1(5 \%) \\
\text { cardiac grade } 3 \\
\text { TEAE was } \\
\text { observed } \\
\text { (congestive heart } \\
\text { failure) }\end{array}$ \\
\hline
\end{tabular}


Table 4. Cont.

\begin{tabular}{|c|c|c|c|c|c|c|c|}
\hline Protocol & Phase & & Treatment & Subjects & Response & TTP/PFS/OS & Toxicity ( $\geq$ G3) \\
\hline $\begin{array}{c}\text { NCT01217957 } \\
\text { C16005 [78] }\end{array}$ & Phase I/II & $\begin{array}{l}\text { Ixa-Rd induction } \\
\text { ASCT } \pm \\
\text { Ixa maintenance }\end{array}$ & $\begin{array}{c}\text { Induction 28-day cycles } \\
\text { (cycles 1-12) Ixazomib p.o. } 4 \mathrm{mg} \\
\text { D1, 8, and } 15 \\
\text { Lenalidomide p.o. } 25 \mathrm{mg} \text { D1-21 } \\
\text { Dexamethasone p.o. } 40 \mathrm{mg} \mathrm{D1}, 8, \\
\text { 15, and } 22 \\
\text { Discontinuation } \rightarrow \text { ASCT } \\
\text { Maintenance } \\
\text { Only for patients who did not } \\
\text { proceed to ASCT: } \\
\text { Single-agent ixazomib, given at } \\
\text { the last tolerated dose during } \\
\text { induction }\end{array}$ & 65 & $\begin{array}{c}63 \% \geq \mathrm{VGPR} \\
32 \% \mathrm{CR} \\
\text { MRD neg } 12.5 \% \text { (MFC) }\end{array}$ & $\begin{array}{c}\text { Median PFS } 35.4 \\
\text { months }\end{array}$ & $\begin{array}{c}\text { Neutropenia } 14 \% \\
\text { Thrombocytopenia } \\
9 \% \\
\text { GIT } 6 \%\end{array}$ \\
\hline
\end{tabular}

NDMM, newly diagnosed multiple myeloma; pts, patients; V, bortezomib; R, lenalidomide; $d$, dex, dexamethasone; $C$, cyclophosphamide; $K$, carfilzomib; $T$, thalidomide; iv, intravenous;

$\mathrm{D}$, day; ASCT, autologous stem-cell transplantation; Mel200, melphalan at $200 \mathrm{mg} / \mathrm{m}^{2}$; Bu, busulfan; Ixa, ixazomib; p.o., orally; G-CSF, granulocyte colony-stimulating factor; Dara,

daratumumab; Pts, patients; PR, partial response; VGPR, very good PR; CR, complete response; sCR, stringent CR; MRD, minimal residual disease; MFC; multiparameter flow cytometry

NGS, next-generation sequencing; N, number; neg, negative; TTP, time to progression; PFS, progression-free survival; OS; overall survival; FU, follow-up; mod, modified; NA; not available;

$\mathrm{NR}$, not reached; $\mathrm{G}$, grade $\mathrm{AE}$, adverse event; TEAE; treatment-emergent AE; GIT, gastrointestinal toxicity. QW, given every week; $\mathrm{Q} 2 \mathrm{~W}$, given every two weeks; $\mathrm{Q} 4 \mathrm{~W}$, given every 4 weeks. 
No randomized trial directly compared VRd vs. VTd induction, although a recent integrated analysis of French and Spanish trials was performed (VRd: PETHEMA, GEM 2012, and IFM 2009; VTd: GEM2005 and IFM 2013-04) [79]. In the Spanish studies, after 6 cycles of induction, the $\geq$ VGPR rate was $66.3 \%$ vs. $51.2 \%$ ( $p=0.003$ ) in VRd vs. VTd groups. In the French studies, after 4 cycles of induction, the $\geq$ VGPR rate was similar between VRd vs. VTd groups ( $57.1 \%$ vs. $56.5 \%)$. The safety profile of VRd was better than that of VTd in both Spanish and French studies, with a lower rate of polyneuropathy (PNP).

High-dose melphalan ( $200 \mathrm{mg} / \mathrm{m}^{2}$, MEL200) followed by ASCT is currently a standard approach in transplant-eligible patients, due to the longer PFS showed in randomized clinical studies comparing ASCT vs. novel agent-based therapy $[50,74,80,81]$, but the role of double vs. single ASCT is still an open issue. The EMN02/HO95 phase III trial showed a benefit in the double ASCT arm in terms of PFS (3-year PFS 73\% vs. $64 \%$ in double vs. single ASCT); this effect was particularly evident in the high cytogenetic risk group, where an OS benefit was also noticed [82]. Similarly, in a meta-analysis including three phase III trials, after a median follow-up of 10 years, double ASCT was significantly better than single ASCT in terms of PFS and OS. Consistent with the EMN02/HO95 data, the benefit was particularly evident in the high-risk group [82], suggesting that, in this patient population, a double ASCT is advisable. Nevertheless, the STAMINA trial did not show any difference in PFS or OS of patients receiving double vs. single ASCT. It is always difficult to perform comparisons between different trials, but the better and prolonged induction (VRD) used in the majority of the patients enrolled in the STAMINA study (whereas 3-4 cycles of VCD were used in the EMN02 study) and the lower compliance to the second ASCT procedure reported in the same study can partially explain the different results [83].

Many trials explored consolidation regimens with the rationale to deepen patient response. In the most recently published PETHEMA study, VRd induction, ASCT, and VRd consolidation produced $\mathrm{a} \geq \mathrm{CR}$ rate of $58 \%$ ( $46 \% \mathrm{sCR}, 12 \% \mathrm{CR}$ ) [75]. These data are consistent with the IFM phase II and phase III studies using VRd consolidation. In the IFM2009 study, VRd consolidation after VRd induction and ASCT showed a similar trend, with the $\geq C R$ rate increasing from $27 \%$ during the induction phase, to $47 \%$ after ASCT to 50\% after consolidation (sCR 40\%, CR 10\%) (Table 4) [70]. Response deepened over time, as well as MRD negativity. In the PETHEMA study, MRD by NGF with a cut-off sensitivity of $3 \times 10^{-6}$ progressively increased from $34.5 \%$ post-induction to $53.4 \%$ post-ASCT, to $58 \%$ after consolidation [75]. The phase III STAMINA and EMN02/HO95 trials were designed to evaluate the role of consolidation vs. no consolidation in a randomized fashion. In the STAMINA trial, the 38-month probability for PFS was respectively $58 \%$ with single ASCT + VRd consolidation, $58 \%$ with tandem ASCT and no consolidation, and 53\% with single ASCT and no consolidation, with no statistical differences [83]. In the EMN02/HO95 study, VRd consolidation after ASCT/bortezomib-melphalan-prednisone (VMP) showed a PFS advantage, with a 5-year PFS of $48 \%$ in the VRd consolidation arm and $41 \%$ in the no consolidation arm $[83,84]$.

In transplant-eligible patients, maintenance therapy is the standard approach after ASCT \pm consolidation. A meta-analysis of three phase III trials randomizing patients to lenalidomide vs. observation/placebo showed a significant benefit in the lenalidomide arm in terms of PFS (median, 53 months vs. 24 months, HR 0.48; $p=0.001$ ) and OS (not reached (NR) vs. 86 months, HR 0.75; $p=0.001$ ) [85]. More recently, the Myeloma XI study confirmed the advantage of lenalidomide maintenance vs. observation after ASCT (median PFS 57 vs. 30 months, HR 0.48, $p<0.0001$; 3-year OS $87.5 \%$ vs. $80.2 \%$, HR $0.69, p=0.01$ ) [86]. Maintenance with lenalidomide can also further deepen the response, with $27-30 \%$ of MRD-positive patients becoming MRD-negative during treatment [87]. Besides its efficacy, the tolerability of continuous lenalidomide maintenance is an important issue. In the meta-analysis, about $30 \%$ of subjects receiving lenalidomide experienced a treatment-related AE that led to discontinuation. Moreover, a higher incidence of SPMs in the lenalidomide arm was reported, although it was outweighed by the advantage of a better disease control [85]. Although the optimal duration is currently considered to be until progressive disease, the median actual duration is 
generally around 2-3 years [85], with retrospective data showing a benefit in patients continuing the drug for at least 2 years $[88,89]$. However, there are currently no randomized prospective data showing evidence that lenalidomide until progressive disease is better than its administration for a prolonged but fixed duration [74].

Maintenance with lenalidomide alone showed conflicting results in high-risk patients $[85,86]$, and the addition of PIs was suggested to be beneficial [90]. In a phase III trial [91], long-term treatment with bortezomib showed to abrogate the negative effect of deletion 17p [92-94]. Moreover, in a randomized study, the administration of the second-generation PI ixazomib as post-ASCT maintenance improved PFS compared to placebo and showed a similar effectiveness for both standard- and high-risk patients [95].

The high rate of deep responses (CR and MRD negativity) obtained after this sequential first-line treatment could further be improved by incorporating the second-generation irreversible PI carfilzomib or adding a fourth drug class, such as the anti-CD38 mAbs.

The incorporation of carfilzomib into first-line treatment was tested in several trials (Table 4) [53,96-98]. In the randomized phase II FORTE trial, carfilzomib was combined either with lenalidomide (KRd) or cyclophosphamide (KCd) with or without ASCT (arm A KCd-ASCT-KCd; arm B KRd-ASCT-KRd; arm C KRd-12 cycles), followed by maintenance with KR or R. After a median follow-up of 26 months, the post-consolidation response rates and MRD negativity were significantly higher in the two KRd arms (B and C) than in the KCd arm (A): $\geq$ VGPR rate was $74 \%$ (arm A), 87\% (arm B), and $87 \%(\operatorname{arm~C})$, and the $\geq C R$ rate $38 \%$ ( $\operatorname{arm~A}), 50 \%(\operatorname{arm~B})$, and $52 \%$ (arm C). The MRD negativity rate by MFC $10^{-5}$ after consolidation was respectively $41 \%$ (arm A), $58 \%$ (arm B), and 54\% (arm C) [99]. The main non-hematologic grade $\geq 3$ AEs were hypertension ( $8 \% \mathrm{KRd}-12 \mathrm{vs.} 3 \% \mathrm{KRd}-\mathrm{ASCT}$ and KCd-ASCT), cardiac AEs ( $2 \%$ KRd- 12 vs. $3 \%$ KRd-ASCT vs. $3 \% \mathrm{KCd}-\mathrm{ASCT})$, infections (13\% KRd- 12 vs. $10 \%$ KRd-ASCT vs. $9 \%$ KCd-ASCT), and hepatic AEs (10\% KRd-12 vs. $8 \%$ KRd-ASCT vs. $1 \%$ KCd-ASCT) [99].

Despite similar MRD negativity rates, a lower number of early relapsing patients was noted in the KRd-ASCT arm than in the KRd-12 arm. This was observed in intermediate + high-risk patients, but not in standard-risk patients, suggesting that, despite the use of second-generation PIs upfront, ASCT could still play a role in this patient population [9].

The addition of an anti-CD38 antibody to triplet regimens has been explored in several trials as well. In the phase III trial CASSIOPEIA, daratumumab-VTd (Dara-VTd) induction-ASCT-Dara-VTd was superior to VTd-ASCT-VTd in terms of response rate after consolidation, with $\geq$ VGPR rate of $83 \%$ vs. $78 \%$, CR rate of $10 \%$ vs. $6 \%$, and sCR rate of $28.9 \%$ vs. $20.3 \%$. MRD negativity $\left(10^{-5}\right)$ after consolidation was reached in $64 \%$ vs. $44 \%$ of patients in the Dara-VTd vs. VTd arms; PFS was significantly improved in the Dara-VTd group, as compared with the control group (HR 0.47, $95 \%$ confidence interval (CI) $0.33-0.67, p<0.0001$ ) [77].

The phase II GRIFFIN study compared Dara-VRd to VRd alone (Table 4). Dara-VRd improved the sCR rate by end of consolidation $(42.4 \%$ vs. $32.0 \%)$. Overall, post-consolidation response was better in the Dara-VRd arm ( $\geq$ VGPR $91 \%, \geq$ CR $52 \%$, of which 59\% MRD-negative) compared to the VRd arm ( $\geq$ VGPR $73 \%, \geq$ CR $42 \%$, of which $24 \%$ MRD-negative); MRD negativity was achieved in $44 \%$ of patients in the Dara-VRd arm after consolidation $\left(10^{-5}\right.$ threshold by NGS) [76].

A phase $\mathrm{Ib}$ study evaluated the addition of daratumumab to carfilzomib-based induction (Dara-KRd). Serious AEs occurred in $46 \%$ of patients. The most common grade 3-4 AEs were lymphopenia (50\%) and neutropenia (23\%); 1 cardiac grade $3 \mathrm{AE}$ was observed (congestive heart failure). In 22 treated patients, ORR was 100\% (CR 5\%, VGPR 86) [11].

Similarly, the addition of isatuximab to KRd is being investigated in the phase II GMMG-CONCEPT study. In the safety run-in phase (10 patients), the overall safety profile was consistent with those previously reported with $\mathrm{KRd}$ and isatuximab. Non-hematologic grade $\geq 3$ AEs were treatment-unrelated cerebral vascular disorder (2 patients), self-limiting ventricular tachycardia 
(1), and diarrhea (1). Three patients experienced a grade 2 infusion-related reaction (IRR) during the first infusion of isatuximab [100].

Quadruplet regimens not including mAbs may allow to achieve deep responses in the majority of patients, preserving the opportunity to use mAbs after induction \pm ASCT in patients not achieving MRD negativity. Bortezomib-lenalidomide-cyclophosphamide-dexamethasone (VRCd) produced a $\geq$ VGPR rate of $33 \%$ after 4 induction cycles [71], while carfilzomib-lenalidomide-cyclophosphamide-dexamethasone (KRCd) produced a $\geq$ VGPR rate of $82 \%$ (MRD negativity $55 \%$ at $10^{-4}-10^{-5}$ sensitivity by flow cytometry) after a median of 4 induction cycles (range 1-12) in transplant-eligible patients [72].

In a small group of patients, the addition of the second-generation oral PI ixazomib to Rd (Ixa-Rd) during induction followed by ASCT or by ixazomib maintenance induced a good response, with $63 \%$ of patients achieving $\geq$ VGPR and $12 \%$ MRD negativity. However, responses were not as deep as those reached in patients treated with upfront daratumumab or carfilzomib, making Ixa-Rd less appealing from a curative perspective [78].

\subsection{ASCT-Ineligible Patients}

ASCT-ineligible patients are a heterogeneous population. Scores predicting mortality and the risk of treatment toxicity in elderly patients have been assessed. Evidence from clinical trials [101] suggested that frailty-adapted therapies should be applied and that mainly fit patients can benefit from strategies aiming at the deepest possible response, due to higher toxicities with similar therapies in intermediate-fit/frail patients that in the end hamper the effectiveness of treatment itself $[102,103]$.

The standard first-line treatment schemes for elderly patients are VMP, Rd, and VRd. In the phase III VISTA trial, VMP was superior to melphalan-prednisone (MP) in terms of CR rate, PFS, and OS (median 56 months vs. 43 months) [104,105].

Continuous Rd significantly increased PFS and OS compared to MPT and also prolonged PFS (but not OS) compared to Rd18 (median PFS 26 months for Rd vs. 21 months for Rd18 and 21.9 months for MPT; 4-year estimated OS 59\% for Rd vs. $56 \%$ for Rd18 and 51\% for MPT). Rd was also generally better tolerated than MPT [106]. In a phase III clinical trial specifically designed for intermediate-fit patients, according to the IMWG frailty score, continuous Rd was compared to Rd induction for 9 cycles followed by R maintenance alone at lower doses: PFS was superimposable, with a better tolerability with Rd-R [107].

VRd was also prospectively compared to $\mathrm{Rd}$ in the SWOGS0777 trial (Table 5), which, however, was not restricted to elderly patients (median age 63 years) [108]. The addition of bortezomib to Rd resulted in significantly improved PFS (43 months vs. 30 months in the Rd group; $p=0.0018$ ) and OS (75 months vs. 64 months in the Rd group; $p=0.025)$. Regarding safety, the VRd combination showed higher rates of grade $\geq 3$ AEs ( 82 vs. $75 \%$ ), neurological toxicities ( $33 \%$ vs. $11 \%$ ), and discontinuation ( $23 \%$ vs. $10 \%$ ). The high neurological toxicity could be due to the two-weekly intravenous infusion of bortezomib used in this trial. In a small phase II study [109], a modified VRd, including lower lenalidomide doses ( $15 \mathrm{mg}$ ) and weekly subcutaneous bortezomib ("VRd lite"), produced a median PFS of 35.1 months and fewer toxic effects. 
Table 5. Newly diagnosed multiple myeloma: selected clinical trials enrolling transplant-ineligible patients.

\begin{tabular}{|c|c|c|c|c|c|c|c|}
\hline Protocol & Phase & & Treatment & Subjects & Response & TTP/PFS/OS & Toxicity ( $\geq$ G3) \\
\hline $\begin{array}{c}\text { NCT00644228 } \\
\text { SWOG S0777 } \\
\text { [108] }\end{array}$ & Phase III & VRd vs. Rd & $\begin{array}{c}\text { VRd 21-day cycles (cycles 1-8) } \\
\text { Bortezomib } 1.3 \mathrm{mg} / \mathrm{m}^{2} \text { iv D1, 4, 8, and } 11+; \\
\text { Lenalidomide p.o. } 25 \mathrm{mg} \text { daily D1-14 } \\
\text { Dexamethasone p.o. } 20 \mathrm{mg} \text { daily D1, 2, 4, 5, 8, 9, } 11 \text {, and } 12 \\
\text { Rd 28-day cycles (cycles } 1-6) \\
\text { Lenalidomide p.o. } 25 \mathrm{mg} \text { D1-21 } \\
\text { Dexamethasone p.o. } 40 \mathrm{mg} \mathrm{D1}, 8,15 \text {, and } 22\end{array}$ & 525 & $\begin{array}{c}\geq \text { VGPR } \\
43 \% \text { vs. } 32 \% \\
\text { CR } 15.7 \% \text { vs. } \\
8.4 \%\end{array}$ & $\begin{array}{c}\text { Median PFS } 43 \\
\text { vs/ } 30 \text { months, } \\
\text { median OS } 75 \text { vs. } \\
64 \text { months }\end{array}$ & $\begin{array}{c}\text { Neurological } \\
\text { AEs } 33 \% \text { vs. } 11 \%\end{array}$ \\
\hline $\begin{array}{l}\text { NCT02195479 } \\
\text { ALCYONE [27] }\end{array}$ & Phase III & $\begin{array}{c}\text { Dara-VMp vs. } \\
\text { VMp }\end{array}$ & $\begin{array}{c}\begin{array}{c}\text { Induction } 42-\text { day cycles } \\
\text { (cycles } 1-9)\end{array} \\
\text { Bortezomib } 1.3 \mathrm{mg} / \mathrm{m}^{2} \text { sc twice-weekly on weeks } 1,2,4, \\
\text { and } 5 \text { of cycle } 1 \text { and once weekly on weeks } 1,2,4 \text {, and } 5 \text { of } \\
\text { cycles } 2-9 \text { ) } \\
\text { Melphalan p.o. } 9 \mathrm{mg} / \mathrm{m}^{2} \text { once-daily on D1-4 } \\
\text { Prednisone p.o. } 60 \mathrm{mg} / \mathrm{m}^{2} \text {, once-daily on D1-4 } \\
\text { Daratumumab iv } 16 \mathrm{mg} / \mathrm{kg} \\
\text { Dexamethasone } 20 \mathrm{mg} \text { once-weekly in cycle } 1 \text {, every } 3 \\
\text { weeks in cycles 2-9, and every } 4 \text { weeks thereafter until } \\
\text { disease progression }\end{array}$ & 706 & $\begin{array}{l}\geq \text { VGPR } 71 \% \text { vs. } \\
49 \% \\
\geq \text { CR } 42 \% \text { vs. } 24 \% \\
\text { MRD neg by } \\
\text { NGS } \\
\text { Dara-VMp arm: } \\
22.3 \% \\
\text { VMp arm: } 6.2 \%\end{array}$ & Median PFS NR & $\begin{array}{c}\text { Neutropenia } 40 \% \\
\text { vs. } 38 \% \\
\text { Anemia } 16 \% \text { vs. } \\
19 \% \text {, } \\
\text { Thrombocytopenia } \\
34 \% \text { vs. } 37 \% \\
\text { Pneumonia } 11 \% \\
\text { vs. } 4 \%\end{array}$ \\
\hline $\begin{array}{c}\text { NCT02252172 } \\
\text { MAIA [110] }\end{array}$ & Phase III & Dara-Rd vs. Rd & $\begin{array}{c}\text { Dara-Rd 28-day cycles } \\
\text { Daratumumab iv } 16 \mathrm{mg} / \mathrm{kg} \text { once-weekly during cycles } 1-2, \\
\text { every } 2 \text { weeks during cycles } 3-6 \text {, and every } 4 \text { weeks } \\
\text { thereafter } \\
\text { Lenalidomide p.o. } 25 \mathrm{mg} \text { D1-21 } \\
\text { Dexamethasone p.o. } 40 \mathrm{mg} \text { D1, } 8,15 \text {, and } 22 \\
\text { Rd 28-day cycle } \\
\text { Lenalidomide p.o. } 25 \mathrm{mg} \text { D1-21 } \\
\text { Dexamethasone p.o. } 40 \mathrm{mg} \text { D1, } 8,15 \text {, and } 22\end{array}$ & 737 & $\begin{array}{l}\geq \text { VGPR } 79 \% \text { vs. } \\
53 \% \\
\geq \text { CR } 47 \% \text { vs. } 24 \% \\
\text { MRD neg by } \\
\text { NGS Dara-Rd } \\
\text { arm: } 24.2 \% \\
\text { Rd arm: } 7.3 \%\end{array}$ & Median PFS NR & $\begin{array}{c}\text { Neutropenia } 50 \% \\
\text { vs. } 35 \% \\
\text { Anemia } 12 \% \text { vs. } \\
20 \% \\
\text { Lymphopenia } \\
15 \% \text { vs. } 11 \% \\
\text { Pneumonia } 14 \% \\
\text { vs. } 8 \%\end{array}$ \\
\hline $\begin{array}{l}\text { NCT02513186 } \\
\text { SARVRD [111] }\end{array}$ & Phase I & $\begin{array}{c}\text { Isa-VRd } \\
\text { induction }+ \\
\text { Isa-Rd } \\
\text { maintenance (16) }\end{array}$ & 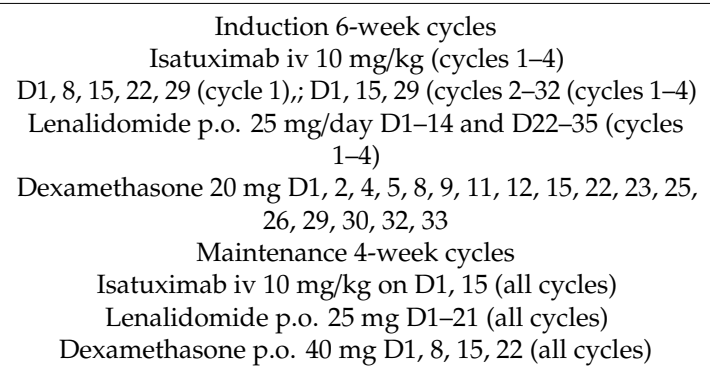 & 22 & $\begin{array}{c}\text { ORR } 93 \% \\
\text { MRD neg by } \\
\text { NGS } 50 \%(33 \% \text { at } \\
\left.10^{-6}\right) \\
\text { NGF } 44 \%(18 \% \text { at } \\
\left.10^{-6}\right)\end{array}$ & NA & $\begin{array}{l}\mathrm{G} \geq 3 \text { AEs were } \\
\text { reported in } 10 \\
(46 \%) \text { and SAEs } \\
\text { in } 4(18 \%) \text { pts } \\
\text { Lymphopenia } \\
\text { (8/22) } \\
\text { Neutropenia } \\
(4 / 22) \\
\text { Thrombocytopenia } \\
\quad(4 / 22)\end{array}$ \\
\hline
\end{tabular}

V, bortezomib; R, lenalidomide; d, dexamethasone; Dara, daratumumab; M, melphalan; p, prednisone; Isa, isatuximab; D, day; iv, intravenous; p.o., orally; sc, subcutaneous; PR, partial response; VGPR, very good PR; CR, complete response; MRD, minimal residual disease; neg, negative; NGS, next-generation sequencing; NGF, next-generation flow; G, grade; AEs; adverse events; SAEs, serious AEs. 
Studies exploring the upfront use of anti-CD38 mAbs in transplant-ineligible patients showed deep responses also in this setting. In the ALCYONE trial, the quadruplet daratumumab-VMP (Dara-VMP) was compared to VMP showing a clear advantage in PFS (HR 0.50, 95\% CI 0.38-0.65, $p<0.001$ ) [27]. At least CR rates were 42 vs. $24 \%$ and MRD negativity rates by NGS were $22.3 \%$ vs. $6.2 \%$, respectively. Safety issues mostly consisted of IRRs (overall $27 \%$, grade $\geq 35 \%$ ) and a high incidence of infections (grade $\geq 3$ pneumonia $11 \%$ vs. $4 \%$ in the Dara-VMP vs. VMP arms).

Similarly, in the phase III randomized MAIA study, Dara-Rd significantly prolonged PFS as compared to Rd (HR 0.56, 95\% CI 0.43-0.73, $p<0.001$ ), with $\geq$ CR rates of $47 \%$ vs. $24 \%$ and MRD negativity in $24 \%$ vs. $7 \%$ patients, respectively. The safety profile was similar in the two arms, but the daratumumab group experienced a higher incidence of neutropenia and infections (including pneumonia) than the Rd group. As in the ALCYONE study, IRRs were reported in the daratumumab arm (overall $40 \%$, mostly of grades 1-2 with an incidence of grade $\geq 3$ IRRs of $2.7 \%$ ) [110].

An ongoing phase I study is investigating isatuximab, in combination with VRd (Isa-VRd): the first report on 22 patients showed good tolerability, with $46 \%$ of grade $\geq 3$ AEs, mostly hematologic. Besides, response rates are promising, with MRD negativity rates $\left(10^{-6}\right)$ by NGS of $33 \%$ and by NGF $18 \%$ [111].

The good results from the upfront use of second-generation PIs in the transplant-eligible setting encouraged its exploration in several clinical trials for the treatment of elderly patients. Carfilzomib associated with melphalan and prednisone (KMP) showed promising results in a phase I/II study, with $90 \%$ ORR and $58 \% \geq$ VGPR rates and about $8 \%$ of grade $\geq 3$ cardiovascular AEs [112]. However, in the phase III CLARION study, KMP failed to outperform VMP in terms of PFS, OS and MRD negativity rates [113]. The safety profile was different between the two arms, with KMP inducing more acute renal failure (any grade $13.9 \%$ vs. $6.2 \%$ ), more cardiac failure (any grade $10.8 \%$ vs. $4.3 \%$ ), and less peripheral neuropathy (grade $\geq 22.5 \%$ vs. $35.1 \%$ ) than VMP.

The association of carfilzomib with cyclophosphamide dexamethasone $(\mathrm{KCd})$ was evaluated in two phase I/II studies, the first adopting the once-weekly carfilzomib schedule and the second the twice-weekly schedule [114,115]. Both trials demonstrated a high efficacy profile (median PFS 35.7 and 35.5 months, respectively; 3-year OS: 72\% and 75\%) with acceptable toxicity. Overall toxicities mainly occurred during the induction phase and the incidence of non-hematologic AEs was similar to that observed with the KMP combination. KCd showed a lower myelotoxicity than KMP and VMP. Of note, few AEs emerged during maintenance. The once- and twice-weekly schedules were compared in a meta-analysis, with no significant differences in terms of efficacy and toxicities, and with a benefit also observed in high-risk patients [116].

\section{Future Perspectives}

Patient fitness is one of the first factors to consider when planning the treatment strategy. Despite the manageable profile of some effective combinations, frail patients can unlikely tolerate full-dose combinations that may induce high MRD negativity. In these patients, disease control rather than cure may be the more realistically achievable goal. Nevertheless, disease control lasting for a few years, even without achieving CR or MRD negativity, could allow very elderly patients to have the same survival of age-matched healthy subjects, considering their actual life expectancy. On the other hand, in fit patients, the outcome-limiting factor is usually disease progression, and a curative approach aiming at sustained MRD negativity could be pursued. This approach should incorporate baseline risk evaluation and dynamic risk evaluation (MRD achievement and duration) during treatment (Figure 1). 


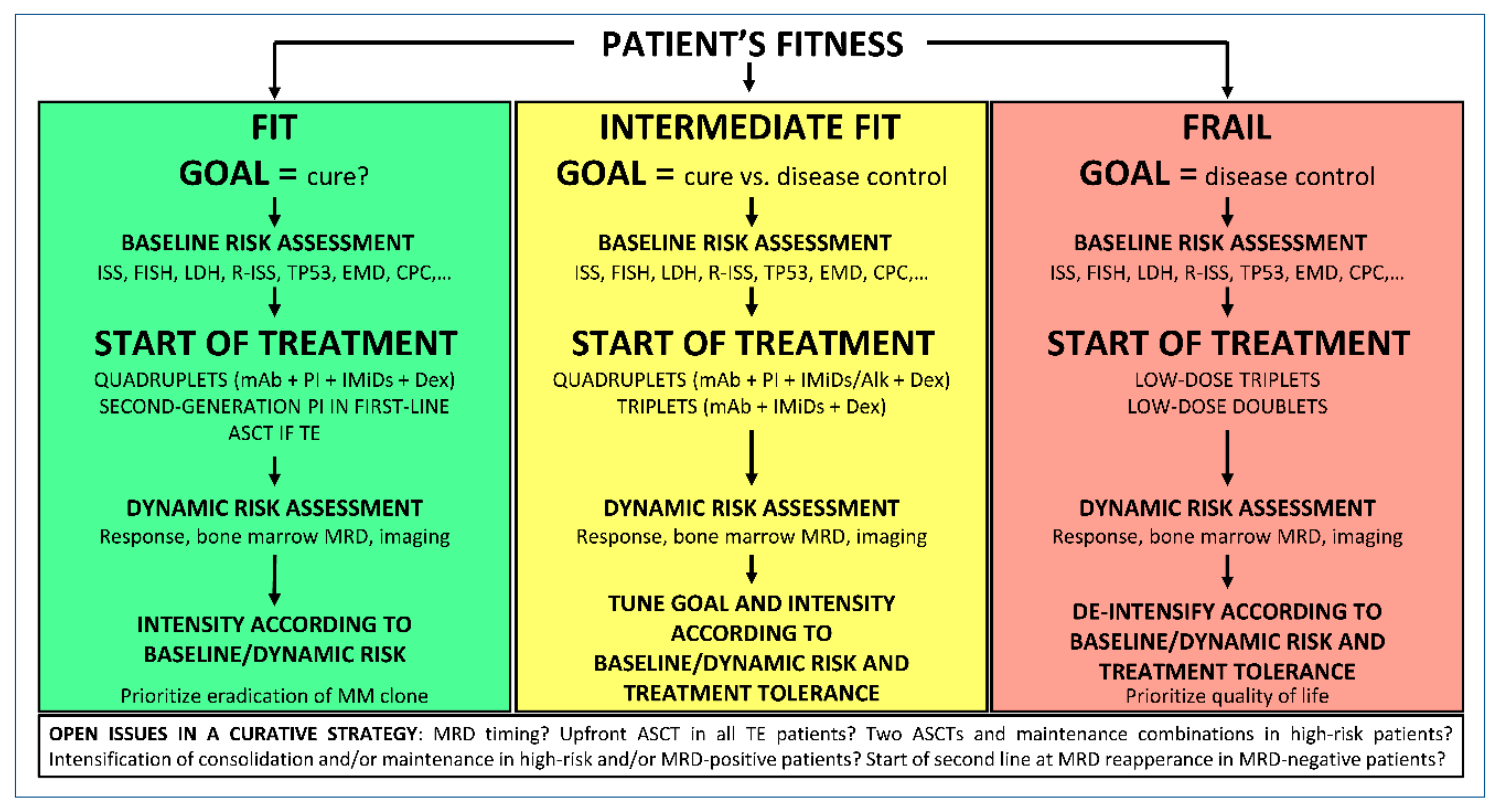

Figure 1. Proposed algorithm to set treatment goal in NDMM patients. ISS, international staging system; FISH, fluorescence in-situ hybridization; LDH, lactate dehydrogenase; R-ISS, revised ISS; EMD, extramedullary disease; CPC, circulating plasma cells; mAb, monoclonal antibody; PI, proteasome inhibitor; IMiDs, immunomodulatory drugs; ASCT, autologous stem cell transplantation; TE, transplant eligible; MRD, minimal residual disease.

Baseline risk factors such as International Staging System (ISS), cytogenetics, lactate dehydrogenase (LDH) levels [117], extramedullary disease [118], circulating plasma cells [119], TP53 mutations [94], and many others can help define our therapeutic strategy. For instance, the use of double ASCT and long-term treatment with a PI plus IMiDs maintenance could be beneficial in the presence of high-risk cytogenetics [92]. The dynamic evaluation of patient risk after the start of treatment can also help tune treatment intensity. Many MRD-driven therapeutic choices are under investigation in clinical trials. One possibility is to evaluate treatment escalation in patients who do not achieve MRD negativity at a pre-specified time point. In particular, this could be the approach for high-risk aggressive MM, mirroring a strategy such as the one used for acute leukemia, where achieving MRD is the goal to achieve cure. Another possibility is to evaluate treatment withholding in patients with sustained MRD negativity. This could be the option with standard-risk disease, where the disease behavior is more similar to that of chronic leukemias. In MRD-negative patients, if a reappearance of MRD is detected, restarting prior therapy if previously interrupted, or starting a different second-line therapy before the development of an overt relapse, can also be explored. Of note, the deferral of treatment is currently recommended, even at the reappearance of a monoclonal component (biochemical relapse), if the increase of the monoclonal component is slow [120]. Treating the reappearance of MRD might be a further step for prolonged disease control but its usefulness should be demonstrated in well-designed trials.

Before using MRD in the treatment of MM, several questions need to be answered. The first question is in which patients we should test MRD (in CR or sCR patients only, or in VGPR patients). The rationale to test MRD in VGPR patients is that, due to the long half-life of serum immunoglobulin ( 1 month), the complete clearance of monoclonal component could take months until all the cells producing it have been eradicated, especially in IgG cases [121]. In these cases, VGPR patients who are MRD-negative in the bone marrow achieve CR in the months following MRD testing. However, MM is a spatially heterogeneous disease and residual plasma cells in extramedullary sites can produce the monoclonal component in VGPR cases in the presence of MRD negativity in the bone marrow. If this is the case, MRD should probably be measured at $\mathrm{SCR}$ and the confirmation of bone marrow 
MRD negativity with imaging techniques should be performed. In the context of a MRD-driven therapy, it is also tricky to evaluate (a) the impact and the likelihood of "false negative" or "false positive" MRD results; (b) the right time point; (c) the reasonably achievable cut-off at a specific time point. For instance, in the transplant-eligible setting, the post-induction time point could be used to investigate different durations and/or intensifications of induction regimens, and to understand whether or not intensification with transplant is necessary. It is possible that, after different treatments, different cut-offs can be achievable. As an example, a $10^{-5}$ negativity can be the reasonable goal after induction, but with prolonged intensification (transplant or further consolidation), a deepest MRD negativity should likely be the goal. This means that different MRD cut-offs at different time points should be considered in planning MRD-driven treatment strategies. Moreover, the question is if treatment decision can rely on a single MRD evaluation, or if, as for all the other response categories, MRD needs to be confirmed. This also affects the choice of the best time point (for instance, can we reasonably use a post-induction time point to make decisions on treatment intensification if we consider an induction with 4 cycles only?). Secondly, we should also consider the importance of MRD duration, particularly in the context of continuous therapy.

In the transplant-eligible setting, a further issue is the role of checking and the feasibility of pursuing MRD negativity in the peripheral blood stem-cell collection. Autografts contaminated with MM cells (MRD-positive autografts at a sensitivity of $10^{-7}$ by NGS) predicted a worse PFS than MRD-negative autografts [122]. However, this effect was mitigated in patients receiving further treatment after ASCT. Indeed, it should be noted that ASCT, consolidation and maintenance, especially with drugs not used during induction, still have the potential to eradicate MRD in a substantial number of patients who are MRD-positive at post-induction time point $[7,8,43,70,123]$.

While the achievement of MRD negativity is clearly predictive of good outcomes, some NDMM patients are characterized by an MGUS-like plasma cell compartment [124]. In these patients, long-term disease control can be accomplished without achieving deep responses, probably due to an immune control of the residual disease. Further research is needed to reliably identify this patient population.

Moreover, the restoration of a physiological immune system at the time of MRD assessment could also play a role in predicting the patients that will possibly not relapse [28].

\section{Conclusions}

In conclusion, we are living exciting times in the field of MM, with many new regimens and strategies in the pipeline and an increasing knowledge of the complexity of the disease. Even if we currently do not have any evidence that we are able to cure MM in the great majority of treated patients, the longer follow-ups of the recent studies will determine the percentage of subjects able to actually maintain a disease-free status for a very long time. New well-designed MRD-driven trials will help us determine if it will be worth aiming at the cure of the disease and what will be the best therapeutic approach to achieve it.

Author Contributions: Substantial contributions to the conception or design: All the authors. Acquisition, analysis, or interpretation of data: All the authors. First draft: M.D., L.B., S.O., and F.G. Supervision: M.B. and F.G. Critical revision for important intellectual content: All the authors. Final approval of the version to be published: All the authors. Agreement to be accountable for all aspects of the work in ensuring that questions related to the accuracy or integrity of any part of the work are appropriately investigated and resolved: All the authors.

Funding: No funding was provided for this contribution.

Conflicts of Interest: S.O. has received honoraria from Amgen, Celgene, and Janssen; and has served on the advisory boards for Adaptive Biotechnologies, Janssen, Amgen, and Takeda. M.B. has received honoraria from Sanofi, Celgene, Amgen, Janssen, Novartis, Bristol-Myers Squibb, and AbbVie; and has received research funding from Sanofi, Celgene, Amgen, Janssen, Novartis, Bristol-Myers Squibb, and Mundipharma. F.G. has received honoraria from Amgen, Bristol-Myers Squibb, Celgene, Janssen, Takeda, and served on the advisory boards for Amgen, Bristol-Myers Squibb, Celgene, Janssen, Roche, Takeda, and AbbVie. The other authors declare no competing financial interests. 


\section{Abbreviations}

\begin{tabular}{|c|c|}
\hline IMWG & International Myeloma Working Group \\
\hline MRD & minimal residual disease \\
\hline NGF & next-generation flow \\
\hline NGS & next-generation sequencing \\
\hline FLC & free light chain \\
\hline M-protein & myeloma protein \\
\hline FCM & flow cytometry \\
\hline SUVmax & maximum standardized uptake value \\
\hline MFC & multiparameter flow cytometry \\
\hline FDG & Fluorodeoxyglucose \\
\hline $\mathrm{PET} / \mathrm{CT}$ & Positron emission tomography/computed tomography \\
\hline $\mathrm{N}$ & number \\
\hline TTP & time to progression \\
\hline $\mathrm{y}$ & year \\
\hline NR & not reached \\
\hline CA & chromosomal abnormalities \\
\hline PCs & plasma cells \\
\hline BMPCs & bone marrow PCs \\
\hline $\mathrm{HR}$ & hazard ratio \\
\hline FLCr & free light chain ratio \\
\hline FISH & fluorescence in situ hybridization \\
\hline Pts & patients \\
\hline V & bortezomib \\
\hline $\mathrm{R}$, Len & lenalidomide \\
\hline d, dex & dexamethasone \\
\hline $\mathrm{T}$ & thalidomide \\
\hline FU & follow-up \\
\hline PFS & progression-free survival \\
\hline OS & overall survival \\
\hline G & grade \\
\hline $\mathrm{P}$ & $p$-value \\
\hline MM & multiple myeloma \\
\hline K & carfilzomib \\
\hline CRAB & hypercalcemia, renal failure, anemia, and bone lesions \\
\hline SMM & smoldering MM \\
\hline ORR & overall response rate \\
\hline Dara & daratumumab \\
\hline ASCT & autologous stem-cell transplantation \\
\hline $\mathrm{Y}$ & years \\
\hline NA & not available \\
\hline iv & intravenous \\
\hline $\mathrm{D}$ & day \\
\hline $\mathrm{AE}$ & adverse event \\
\hline $\mathrm{sc}$ & subcutaneous \\
\hline p.o. & orally \\
\hline G-CSF & granulocyte colony-stimulating factor \\
\hline Obs. & observation \\
\hline TE & Transplant-eligible \\
\hline NTE & non-transplant-eligible \\
\hline NDMM & newly diagnosed multiple myeloma \\
\hline $\mathrm{C}$ & cyclophosphamide \\
\hline PD & progressive disease \\
\hline MR & minimal response \\
\hline
\end{tabular}




$\begin{array}{ll}\text { PR } & \text { partial response } \\ \text { VGPR } & \text { very good PR } \\ \text { CR } & \text { complete response } \\ \text { nCR } & \text { near CR } \\ \text { SCR } & \text { stringent CR } \\ \text { CHF } & \text { congestive heart failure } \\ \text { SPMs } & \text { second primary malignancies } \\ \text { MRD neg } & \text { MRD negative/negativity } \\ \text { M, Mel } & \text { melphalan } \\ \text { Mel200 } & \text { melphalan at 200 mg/m }{ }^{2} \\ \text { Bu } & \text { busulfan } \\ \text { p } & \text { prednisone } \\ \text { Ixa } & \text { ixazomib } \\ \text { SAEs } & \text { serious AEs } \\ \text { TEAEs } & \text { treatment-emergent AEs } \\ \text { GIT } & \text { gastrointestinal toxicity } \\ \text { QW } & \text { given every week } \\ \text { Q2W } & \text { given every two weeks } \\ \text { Q4W } & \text { given every 4 weeks } \\ \text { CI } & \text { confidence interval } \\ \text { ISS } & \text { International Staging System } \\ \text { R-ISS } & \text { Revised ISS } \\ \text { LDH } & \text { lactate dehydrogenase } \\ \text { EMD } & \text { extramedullary disease } \\ \text { CPC } & \text { circulating plasma cells } \\ \text { mAb } & \text { monoclonal antibody } \\ \text { PI } & \text { proteasome inhibitor } \\ \text { IMiDs } & \text { immunomodulatory drugs } \\ & \end{array}$

\section{References}

1. Palumbo, A.; Anderson, K. Multiple myeloma. N. Engl. J. Med. 2011, 364, 1046-1060. [CrossRef] [PubMed]

2. Ferlay, J.; Colombet, M.; Soerjomataram, I.; Dyba, T.; Randi, G.; Bettio, M.; Gavin, A.; Visser, O.; Bray, F. Cancer incidence and mortality patterns in Europe: Estimates for 40 countries and 25 major cancers in 2018. Eur. J. Cancer 2018, 103, 356-387. [CrossRef] [PubMed]

3. Nandakumar, B.; Binder, M.; Dispenzieri, A.; Kapoor, P.; Buadi, F.; Gertz, M.A.; Lacy, M.; Dingli, D.; Hwa, L.; Leung, N.; et al. Continued improvement in survival in multiple myeloma (MM) including high-risk patients. J. Clin. Oncol. 2019, 37, Abstract \#8039 [ASCO 2019 Meeting]. [CrossRef]

4. Castañeda-Avila, M.A.; Ortiz-Ortiz, K.J.; Torres-Cintrón, C.R.; Birmann, B.M.; Epstein, M.M. Trends in cause of death among patients with multiple myeloma in Puerto Rico and the United States SEER population, 1987-2013. Int. J. Cancer 2019, 146, 35-43. [CrossRef] [PubMed]

5. Wang, M.; Delasalle, K.; Feng, L.; Thomas, S.; Giralt, S.; Qazilbash, M.; Handy, B.; Lee, J.J.; Alexanian, R. $\mathrm{CR}$ represents an early index of potential long survival in multiple myeloma. Bone Marrow Transplant. 2010, 45, 498-504. [CrossRef]

6. Ravi, P.; Kumar, S.K.; Cerhan, J.R.; Maurer, M.J.; Dingli, D.; Ansell, S.M.; Rajkumar, S.V. Defining cure in multiple myeloma: A comparative study of outcomes of young individuals with myeloma and curable hematologic malignancies. Blood Cancer J. 2018, 8, 26. [CrossRef]

7. Avet-Loiseau, H.; Moreau, P.; Attal, M.; Hulin, C.; Arnulf, B.; Corre, J.; Garderet, L.; Karlin, L.; Lambert, J.; Macro, M.; et al. Efficacy of daratumumab (DARA) + bortezomib/thalidomide/dexamethasone (D-VTd) in transplant-eligible newly diagnosed multiple myeloma (TE NDMM) based on minimal residual disease (MRD) status: Analysis of the CASSIOPEIA trial. J. Clin. Oncol. 2019, 37, Abstract \#8017 [ASCO 2019 International Meeting]. [CrossRef]

8. Zimmerman, T.; Raje, N.S.; Vij, R.; Reece, D.; Berdeja, J.G.; Stephens, L.A.; McDonnell, K.; Rosenbaum, C.A.; Jasielec, J.; Richardson, P.G.; et al. Final Results of a Phase 2 Trial of Extended Treatment (tx) with Carfilzomib 
(CFZ), Lenalidomide (LEN), and Dexamethasone (KRd) Plus Autologous Stem Cell Transplantation (ASCT) in Newly Diagnosed Multiple Myeloma (NDMM). Blood 2016, 128, Abstract \#675 [ASH 2016 58th Meeting]. [CrossRef]

9. Gay, F.; Cerrato, C.; Petrucci, M.T.; Zambello, R.; Gamberi, B.; Ballanti, S.; Omedè, P.; Palmieri, S.; Troia, R.; Spada, S.; et al. Efficacy of carfilzomib lenalidomide dexamethasone (KRd) with or without transplantation in newly diagnosed myeloma according to risk status: Results from the forte trial. J. Clin. Oncol. 2019, 37, Abstract \#8002 [ASCO 2019 Annual Meeting]. [CrossRef]

10. Voorhees, P.M.; Rodriguez, C.; Reeves, B.; Nathwani, N.; Costa, L.J.; Lutska, Y.; Hoehn, D.; Pei, H.; Ukropec, J.; Qi, M.; et al. Efficacy and Updated Safety Analysis of a Safety Run-in Cohort from Griffin, a Phase 2 Randomized Study of Daratumumab (Dara), Bortezomib (V), Lenalidomide (R), and Dexamethasone (D.; Dara-Vrd) Vs. Vrd in Patients (Pts) with Newly Diagnosed (ND) Multiple, M. Blood 2018, 132, Abstract \#151 [ASH 2018 60th Meeting]. [CrossRef]

11. Jakubowiak, A.J.; Chari, A.; Lonial, S.; Weiss, B.M.; Comenzo, R.L.; Wu, K.; Khokhar, N.Z.; Wang, J.; Doshi, P.; Usmani, S.Z. Daratumumab (DARA) in combination with carfilzomib, lenalidomide, and dexamethasone (KRd) in patients (pts) with newly diagnosed multiple myeloma (MMY1001): An open-label, phase 1b study. J. Clin. Oncol. 2017, 35, Abstract \#8000 [ASCO 2017 Annual Meeting]. [CrossRef]

12. Lokhorst, H.M.; Schmidt-Wolf, I.; Sonneveld, P.; van der Holt, B.; Martin, H.; Barge, R.; Bertsch, U.; Schlenzka, J.; Bos, G.M.J.; Croockewit, S.; et al. Thalidomide in induction treatment increases the very good partial response rate before and after high-dose therapy in previously untreated multiple myeloma. Haematologica 2008, 93, 124-127. [CrossRef] [PubMed]

13. Lahuerta, J.-J.; Paiva, B.; Vidriales, M.-B.; Cordón, L.; Cedena, M.-T.; Puig, N.; Martinez-Lopez, J.; Rosiñol, L.; Gutierrez, N.C.; Martín-Ramos, M.-L.; et al. Depth of Response in Multiple Myeloma: A Pooled Analysis of Three PETHEMA/GEM Clinical Trials. J. Clin. Oncol. 2017, 35, 2900-2910. [CrossRef] [PubMed]

14. Rajkumar, S.V.; Harousseau, J.-L.; Durie, B.; Anderson, K.C.; Dimopoulos, M.; Kyle, R.; Blade, J.; Richardson, P.; Orlowski, R.; Siegel, D.; et al. Consensus recommendations for the uniform reporting of clinical trials: Report of the International Myeloma Workshop Consensus Panel 1. Blood 2011, 117, 4691-4695. [CrossRef] [PubMed]

15. Kumar, S.; Paiva, B.; Anderson, K.C.; Durie, B.; Landgren, O.; Moreau, P.; Munshi, N.; Lonial, S.; Bladé, J.; Mateos, M.-V.; et al. International Myeloma Working Group consensus criteria for response and minimal residual disease assessment in multiple myeloma. Lancet Oncol. 2016, 17, e328-e346. [CrossRef]

16. Paiva, B.; Gutiérrez, N.C.; Rosiñol, L.; Vídriales, M.-B.; Montalbán, M.-Á.; Martínez-López, J.; Mateos, M.-V.; Cibeira, M.-T.; Cordón, L.; Oriol, A.; et al. High-risk cytogenetics and persistent minimal residual disease by multiparameter flow cytometry predict unsustained complete response after autologous stem cell transplantation in multiple myeloma. Blood 2012, 119, 687-691. [CrossRef]

17. Nanni, C.; Zamagni, E.; Versari, A.; Chauvie, S.; Bianchi, A.; Rensi, M.; Bellò, M.; Rambaldi, I.; Gallamini, A.; Patriarca, F.; et al. Image interpretation criteria for FDG PET/CT in multiple myeloma: A new proposal from an Italian expert panel. IMPeTUs (Italian Myeloma criteria for PET USe). Eur. J. Nucl. Med. Mol. Imaging 2016, 43, 414-421. [CrossRef]

18. Flores-Montero, J.; de Tute, R.; Paiva, B.; Perez, J.J.; Böttcher, S.; Wind, H.; Sanoja, L.; Puig, N.; Lecrevisse, Q.; Vidriales, M.B.; et al. Immunophenotype of normal vs. myeloma plasma cells: Toward antibody panel specifications for MRD detection in multiple myeloma. Cytometry Part B Clin. Cytom. 2016, 90, 61-72. [CrossRef]

19. Stetler-Stevenson, M.; Paiva, B.; Stoolman, L.; Lin, P.; Jorgensen, J.L.; Orfao, A.; Van Dongen, J.; Rawstron, A.C. Consensus guidelines for myeloma minimal residual disease sample staining and data acquisition. Cytometry Part B Clin. Cytom. 2016, 90, 26-30. [CrossRef]

20. Flores-Montero, J.; Sanoja-Flores, L.; Paiva, B.; Puig, N.; García-Sánchez, O.; Böttcher, S.; Van Der Velden, V.H.J.; Pérez-Morán, J.J.; Vidriales, M.B.; García-Sanz, R.; et al. Next Generation Flow for highly sensitive and standardized detection of minimal residual disease in multiple myeloma. Leukemia 2017, 31, 2094-2103. [CrossRef]

21. FDA. Authorizes First Next Generation Sequencing-Based Test to Detect Very Low Levels of Remaining Cancer Cells in Patients with Acute Lymphoblastic Leukemia or Multiple Myeloma. Available online: https://www.fda.gov/news-events/press-announcements/fda-authorizes-first-next-generation-sequencingbased-test-detect-very-low-levels-remaining-cancer (accessed on 23 October 2019). 
22. Faham, M.; Zheng, J.; Moorhead, M.; Carlton, V.E.H.; Stow, P.; Coustan-Smith, E.; Pui, C.H.; Campana, D. Deep-sequencing approach for minimal residual disease detection in acute lymphoblastic leukemia. Blood 2012, 120, 5173-5180. [CrossRef] [PubMed]

23. Ladetto, M.; Brüggemann, M.; Monitillo, L.; Ferrero, S.; Pepin, F.; Drandi, D.; Barbero, D.; Palumbo, A.; Passera, R.; Boccadoro, M.; et al. Next-generation sequencing and real-time quantitative PCR for minimal residual disease detection in B-cell disorders. Leukemia 2014, 28, 1299-1307. [CrossRef] [PubMed]

24. Avet-Loiseau, H.; Bene, M.C.; Wuilleme, S.; Corre, J.; Attal, M.; Arnulf, B.; Garderet, L.; Macro, M.; Stoppa, A.-M.; Delforge, M.; et al. Concordance of Post-consolidation Minimal Residual Disease Rates by Multiparametric Flow Cytometry and Next-generation Sequencing in CASSIOPEIA. In Proceedings of the 17th International Myeloma Workshop, Boston, MA, USA, 12-15 September 2019; Volume 8; [Abstract \#OAB-004].

25. Rawstron, A.C.; Gregory, W.M.; de Tute, R.M.; Davies, F.E.; Bell, S.E.; Drayson, M.T.; Cook, G.; Jackson, G.H.; Morgan, G.J.; Child, J.A.; et al. Minimal residual disease in myeloma by flow cytometry: Independent prediction of survival benefit per log reduction. Blood 2015, 125, 1932-1935. [CrossRef] [PubMed]

26. Perrot, A.; Lauwers-Cances, V.; Corre, J.; Robillard, N.; Hulin, C.; Chretien, M.L.; Dejoie, T.; Maheo, S.; Stoppa, A.M.; Pegourie, B.; et al. Minimal residual disease negativity using deep sequencing is a major prognostic factor in multiple myeloma. Blood 2018, 132, 2456-2464. [CrossRef] [PubMed]

27. Mateos, M.-V.; Dimopoulos, M.A.; Cavo, M.; Suzuki, K.; Jakubowiak, A.; Knop, S.; Doyen, C.; Lucio, P.; Nagy, Z.; Kaplan, P.; et al. Daratumumab plus Bortezomib, Melphalan, and Prednisone for Untreated Myeloma. N. Engl. J. Med. 2018, 378, 518-528. [CrossRef] [PubMed]

28. Paiva, B.; Cedena, M.T.; Puig, N.; Arana, P.; Vidriales, M.B.; Cordon, L.; Flores-Montero, J.; Gutierrez, N.C.; Martín-Ramos, M.L.; Martinez-Lopez, J.; et al. Minimal residual disease monitoring and immune profiling in multiple myeloma in elderly patients. Blood 2016, 127, 3165-3174. [CrossRef] [PubMed]

29. Rawstron, A.C.; Child, J.A.; de Tute, R.M.; Davies, F.E.; Gregory, W.M.; Bell, S.E.; Szubert, A.J.; Navarro-Coy, N.; Drayson, M.T.; Feyler, S.; et al. Minimal Residual Disease Assessed by Multiparameter Flow Cytometry in Multiple Myeloma: Impact on Outcome in the Medical Research Council Myeloma IX Study. J. Clin. Oncol. 2013, 31, 2540-2547. [CrossRef]

30. Oliva, S.; op Bruinink, D.H.; Ř́lhová, L.; Spada, S.; van der Holt, B.; Troia, R.; Gambella, M.; Pantani, L.; Grammatico, S.; Gilestro, M.; et al. Minimal residual disease (MRD) monitoring by multiparameter flow cytometry (MFC) in newly diagnosed transplant eligible multiple myeloma (MM) patients: Results from the EMN02/HO95 phase 3 trial. J. Clin. Oncol. 2017, 35. [CrossRef]

31. Paiva, B.; Puig, N.; Cedena, M.T.; Cordon, L.; Vidriales, M.-B.; Burgos, L.; Flores-Montero, J.; Lopez-Anglada, L.; Gutierrez, N.; Calasanz, M.J.; et al. Impact of Next-Generation Flow (NGF) Minimal Residual Disease (MRD) Monitoring in Multiple Myeloma (MM): Results from the Pethema/GEM2012 Trial. Blood 2017, 130, Abstract \#905 [ASH 2017 58th Meeting]. [CrossRef]

32. Bladé, J.; Fernández De Larrea, C.; Rosiñol, L.; Cibeira, M.T.; Jiménez, R.; Powles, R. Soft-tissue plasmacytomas in multiple myeloma: Incidence, mechanisms of extramedullary spread, and treatment approach. J. Clin. Oncol. 2011, 29, 3805-3812. [CrossRef]

33. Moreau, P. PET-CT in MM: A new definition of CR. Blood 2011, 118, 5984-5985. [CrossRef] [PubMed]

34. Moreau, P.; Attal, M.; Caillot, D.; Macro, M.; Karlin, L.; Garderet, L.; Facon, T.; Benboubker, L.; Escoffre-Barbe, M.; Stoppa, A.-M.; et al. Prospective Evaluation of Magnetic Resonance Imaging and [18F]Fluorodeoxyglucose Positron Emission Tomography-Computed Tomography at Diagnosis and Before Maintenance Therapy in Symptomatic Patients With Multiple Myeloma Included in the IFM/DFCI 2009 Trial. J. Clin. Oncol. 2017, 35, 2911-2918. [CrossRef] [PubMed]

35. Zamagni, E.; Patriarca, F.; Nanni, C.; Zannetti, B.; Englaro, E.; Pezzi, A.; Tacchetti, P.; Buttignol, S.; Perrone, G.; Brioli, A.; et al. Prognostic relevance of 18-F FDG PET/CT in newly diagnosed multiple myeloma patients treated with up-front autologous transplantation. Blood 2011, 118, 5989-5995. [CrossRef] [PubMed]

36. Bartel, T.B.; Haessler, J.; Brown, T.L.Y.; Shaughnessy, J.D.; van Rhee, F.; Anaissie, E.; Alpe, T.; Angtuaco, E.; Walker, R.; Epstein, J.; et al. F18-fluorodeoxyglucose positron emission tomography in the context of other imaging techniques and prognostic factors in multiple myeloma. Blood 2009, 114, 2068-2076. [CrossRef]

37. Zamagni, E.; Nanni, C.; Dozza, L.; Carlier, T.; Tacchetti, P.; Versari, A.; Chauvie, S.; Gallamini, A.; Attal, M.; Gamberi, B.; et al. Standardization of 18F-FDG PET/CT According to Deauville Criteria for MRD Evaluation 
in Newly Diagnosed Transplant Eligible Multiple Myeloma Patients: Joined Analysis of Two Prospective Randomized Phase III Trials. Blood 2018, 132, Abstract \#257 [ASH 2018 60th Meeting]. [CrossRef]

38. Rasche, L.; Alapat, D.; Kumar, M.; Gershner, G.; McDonald, J.; Wardell, C.P.; Samant, R.; Van Hemert, R.; Epstein, J.; Williams, A.F.; et al. Combination of flow cytometry and functional imaging for monitoring of residual disease in myeloma. Leukemia 2019, 33, 1713-1722. [CrossRef]

39. Mazzotti, C.; Buisson, L.; Maheo, S.; Perrot, A.; Chretien, M.-L.; Leleu, X.; Hulin, C.; Manier, S.; Hébraud, B.; Roussel, M.; et al. Myeloma MRD by deep sequencing from circulating tumor DNA does not correlate with results obtained in the bone marrow. Blood Adv. 2018, 2, 2811-2813. [CrossRef]

40. Avet-Loiseau, H.; San-Miguel, J.F.; Casneuf, T.; Iida, S.; Lonial, S.; Usmani, S.Z.; Spencer, A.; Moreau, P.; Plesner, T.; Weisel, K.; et al. Evaluation of Sustained Minimal Residual Disease (MRD) Negativity in Relapsed/Refractory Multiple Myeloma (RRMM) Patients (Pts) Treated with Daratumumab in Combination with Lenalidomide Plus Dexamethasone (D-Rd) or Bortezomib Plus Dexamethasone (D-Vd): An. Blood 2018, 132, Abstract \#3272 [ASH 2018 60th Meeting]. [CrossRef]

41. Radich, J.P.; Deininger, M.; Abboud, C.N.; Altman, J.K.; Berman, E.; Bhatia, R.; Bhatnagar, B.; Curtin, P.; DeAngelo, D.J.; Gotlib, J.; et al. Chronic myeloid leukemia, version 1.2019. JNCCN J. Natl. Compr. Cancer Netw. 2018, 16, 1108-1135. [CrossRef]

42. Saussele, S.; Richter, J.; Guilhot, J.; Gruber, F.X.; Hjorth-Hansen, H.; Almeida, A.; Janssen, J.J.W.M.; Mayer, J.; Koskenvesa, P.; Panayiotidis, P.; et al. Discontinuation of tyrosine kinase inhibitor therapy in chronic myeloid leukaemia (EURO-SKI): A prespecified interim analysis of a prospective, multicentre, non-randomised, trial. Lancet Oncol. 2018, 19, 747-757. [CrossRef]

43. Gu, J.; Liu, J.; Chen, M.; Huang, B.; Li, J. Longitudinal Flow Cytometry Identified “Minimal Residual Disease" (MRD) Evolution Patterns for Predicting the Prognosis of Patients with Transplant-Eligible Multiple Myeloma. Biol. Blood Marrow Transplant. 2018, 24, 2568-2574. [CrossRef]

44. Rajkumar, S.V.; Dimopoulos, M.A.; Palumbo, A.; Blade, J.; Merlini, G.; Mateos, M.-V.; Kumar, S.; Hillengass, J.; Kastritis, E.; Richardson, P.; et al. International Myeloma Working Group updated criteria for the diagnosis of multiple myeloma. Lancet Oncol. 2014, 15, e538-e548. [CrossRef]

45. Lakshman, A.; Vincent Rajkumar, S.; Buadi, F.K.; Binder, M.; Gertz, M.A.; Lacy, M.Q.; Dispenzieri, A.; Dingli, D.; Fonder, A.L.; Hayman, S.R.; et al. Risk stratification of smoldering multiple myeloma incorporating revised IMWG diagnostic criteria. Blood Cancer J. 2018, 8. [CrossRef] [PubMed]

46. Cherry, B.M.; Korde, N.; Kwok, M.; Manasanch, E.E.; Bhutani, M.; Mulquin, M.; Zuchlinski, D.; Yancey, M.A.; Maric, I.; Calvo, K.R.; et al. Modeling progression risk for smoldering multiple myeloma: Results from a prospective clinical study. Proc. Leuk. Lymphoma 2013, 54, 2215-2218. [CrossRef] [PubMed]

47. Kyle, R.A.; Remstein, E.D.; Therneau, T.M.; Dispenzieri, A.; Kurtin, P.J.; Hodnefield, J.M.; Larson, D.R.; Plevak, M.F.; Jelinek, D.F.; Fonseca, R.; et al. Clinical Course and Prognosis of Smoldering (Asymptomatic) Multiple Myeloma. N. Engl. J. Med. 2007, 356, 2582-2590. [CrossRef]

48. Pérez-Persona, E.; Vidriales, M.B.; Mateo, G.; García-Sanz, R.; Mateos, M.V.; De Coca, A.G.; Galende, J.; Martín-Nuñez, G.; Alonso, J.M.; De Heras, N.L.; et al. New criteria to identify risk of progression in monoclonal gammopathy of uncertain significance and smoldering multiple myeloma based on multiparameter flow cytometry analysis of bone marrow plasma cells. Blood 2007, 110, 2586-2592. [CrossRef]

49. San Miguel, J.; Mateos, M.-V.; Gonzalez, V.; Dimopoulos, M.A.; Kastritis, E.; Hajek, R.; de Larrea Rodríguez, C.; Morgan, G.J.; Merlini, G.; Mangiacavalli, S.; et al. Updated risk stratification model for smoldering multiple myeloma (SMM) incorporating the revised IMWG diagnostic criteria. J. Clin. Oncol. 2019, 37, Abstract \#8000 [ASCO 2019 Annual Meeting]; Updated data presented at the meeting. [CrossRef]

50. Gay, F.; Oliva, S.; Petrucci, M.T.; Conticello, C.; Catalano, L.; Corradini, P.; Siniscalchi, A.; Magarotto, V.; Pour, L.; Carella, A.; et al. Chemotherapy plus lenalidomide versus autologous transplantation, followed by lenalidomide plus prednisone versus lenalidomide maintenance, in patients with multiple myeloma: A randomised, multicentre, phase 3 trial. Lancet Oncol. 2015, 16, 1617-1629. [CrossRef]

51. López-Corral, L.; Gutiérrez, N.C.; Vidriales, M.B.; Mateos, M.V.; Rasillo, A.; García-Sanz, R.; Paiva, B.; San Miguel, J.F. The progression from MGUS to smoldering myeloma and eventually to multiple myeloma involves a clonal expansion of genetically abnormal plasma cells. Clin. Cancer Res. 2011, 17, 1692-1700. [CrossRef]

52. Mateos, M.V.; Hernández, M.T.; Giraldo, P.; de la Rubia, J.; de Arriba, F.; Corral, L.L.; Rosiñol, L.; Paiva, B.; Palomera, L.; Bargay, J.; et al. Lenalidomide plus dexamethasone versus observation in patients with high-risk 
smouldering multiple myeloma (QuiRedex): Long-term follow-up of a randomised, controlled, phase 3 trial. Lancet Oncol. 2016, 17, 1127-1136. [CrossRef]

53. Korde, N.; Roschewski, M.; Zingone, A.; Kwok, M.; Manasanch, E.E.; Bhutani, M.; Tageja, N.; Kazandjian, D.; Mailankody, S.; Wu, P.; et al. Treatment With Carfilzomib-Lenalidomide-Dexamethasone With Lenalidomide Extension in Patients With Smoldering or Newly Diagnosed Multiple Myeloma. JAMA Oncol. 2015, 1, 746. [CrossRef] [PubMed]

54. Mateos, M.-V.; Martínez-López, J.; Rodríguez-Otero, P.; de la Calle, G.V.; González, M.-S.; Oriol, A.; Gutiérrez, N.-C.; Paiva, B.; Rios, R.; Rosiñol, L.; et al. Curative strategy (gem-cesar) for high-risk smoldering myeloma: Carfilzomib, lenalidomide and dexamethasone (krd) as induction followed by hdt-asct, consolidation with krd and maintenance with rd. HemaSphere 2019, 3, 390. [CrossRef]

55. Mailankody, S.; Salcedo, M.; Tavitian, E.; Korde, N.; Lendvai, N.; Hassoun, H.; Lesokhin, A.M.; Lahoud, O.B.; Smith, E.L.; Hultcrantz, M.; et al. Ixazomib and dexamethasone in high risk smoldering multiple myeloma: A clinical and correlative pilot study. J. Clin. Oncol. 2019, 37,Abstract \#8051 [ASCO 2019 Annual Meeting]. [CrossRef]

56. Jagannath, S.; Laubach, J.; Wong, E.; Stockerl-Goldstein, K.; Rosenbaum, C.; Dhodapkar, M.; Jou, Y.-M.; Lynch, M.; Robbins, M.; Shelat, S.; et al. Elotuzumab monotherapy in patients with smouldering multiple myeloma: A phase 2 study. Br. J. Haematol. 2018, 182, 495-503. [CrossRef] [PubMed]

57. Liu, C.; Ghobrial, I.M.; Bustoros, M.; Reyes, K.; Hornburg, K.; Badros, A.Z.; Vredenburgh, J.J.; Boruchov, A.; Matous, J.V.; Caola, A.; et al. Phase II Trial of Combination of Elotuzumab, Lenalidomide, and Dexamethasone in High-Risk Smoldering Multiple Myeloma. Blood 2018, 132, Abstract \#154 [ASH 2018 60th Meeting]. [CrossRef]

58. Bustoros, M.; Liu, C.; Reyes, K.; Hornburg, K.; Guimond, K.; Styles, R.; Savell, A.; Berrios, B.; Warren, D.; Dumke, H.; et al. Phase II Trial of the Combination of Ixazomib, Lenalidomide, and Dexamethasone in High-Risk Smoldering Multiple Myeloma. Blood 2018, 132, Abstract \#804 [ASH 2018 60th Meeting]. [CrossRef]

59. Brighton, T.A.; Khot, A.; Harrison, S.J.; Ghez, D.; Weiss, B.M.; Kirsch, A.; Magen, H.; Gironella, M.; Oriol, A.; Streetly, M.; et al. Randomized, double-blind, placebo-controlled, multicenter study of siltuximab in high-risk smoldering multiple myeloma. Clin. Cancer Res. 2019, 25, 3772-3775. [CrossRef]

60. Landgren, O.; Cavo, M.; Chari, A.; Cohen, Y.C.; Spencer, A.; Voorhees, P.M.; Estell, J.; Sandhu, I.; Jenner, M.; Williams, C.; et al. Updated Results from the Phase 2 Centaurus Study of Daratumumab (DARA) Monotherapy in Patients with Intermediate-Risk or High-Risk Smoldering Multiple Myeloma (SMM). Blood 2018, 132, Abstract \#1994 [ASH 2018 60th Meeting]. [CrossRef]

61. Rajkumar, S.V.; Voorhees, P.M.; Goldschmidt, H.; Baker, R.I.; Bandekar, R.; Kuppens, S.; Neff, T.; Qi, M.; Dimopoulos, M.A. Randomized, open-label, phase 3 study of subcutaneous daratumumab (DARA SC) versus active monitoring in patients (Pts) with high-risk smoldering multiple myeloma (SMM): AQUILA. J. Clin. Oncol. 2018, 36, Abstract \#TPS8062 (ASCO 2018 Annual Meeting]. [CrossRef]

62. Lonial, S.; Jacobus, S.; Fonseca, R.; Weiss, M.; Kumar, S.; Orlowski, R.Z.; Kaufman, J.L.; Yacoub, A.M.; Buadi, F.K.; O'Brien, T.; et al. Randomized Trial of Lenalidomide Versus Observation in Smoldering Multiple Myeloma. J. Clin. Oncol. 2019, 37, Abstract \#8001 [ASCO 2019 Annual Meeting]. [CrossRef]

63. Barlogie, B.; Jagannath, S.; Desikan, K.R.; Mattox, S.; Vesole, D.; Siegel, D.; Tricot, G.; Munshi, N.; Fassas, A.; Singhal, S.; et al. Total therapy with tandem transplants for newly diagnosed multiple myeloma. Blood 1999, 93, 55-65. [CrossRef] [PubMed]

64. Barlogie, B.; Mitchell, A.; van Rhee, F.; Epstein, J.; Yaccoby, S.; Zangari, M.; Heuck, C.; Hoering, A.; Morgan, G.J.; Crowley, J. Curing Multiple Myeloma (MM) with Total Therapy (TT). Blood 2014, 124, Abstract \#195 [ASH 2014 56th Meeting]. [CrossRef]

65. Mateos, M.V.; San Miguel, J.F. Management of multiple myeloma in the newly diagnosed patient. Hematology 2017, 2017, 498-507. [CrossRef] [PubMed]

66. Moreau, P.; Attal, M.; Facon, T. Frontline therapy of multiple myeloma. Blood 2015, 125, 3076-3084. [CrossRef]

67. Harousseau, J.-L.; Attal, M.; Avet-Loiseau, H.; Marit, G.; Caillot, D.; Mohty, M.; Lenain, P.; Hulin, C.; Facon, T.; Casassus, P.; et al. Bortezomib plus dexamethasone is superior to vincristine plus doxorubicin plus dexamethasone as induction treatment prior to autologous stem-cell transplantation in newly diagnosed multiple myeloma: Results of the IFM 2005-01 phase III trial. J. Clin. Oncol. 2010, 28, 4621-4629. [CrossRef] 
68. Gay, F.; Engelhardt, M.; Terpos, E.; Wäsch, R.; Giaccone, L.; Auner, H.W.; Caers, J.; Gramatzki, M.; van de Donk, N.; Oliva, S.; et al. From transplant to novel cellular therapies in multiple myeloma: EMN guidelines and future perspectives. Haematologica 2018, 103, 197-211. [CrossRef]

69. Moreau, P.; Hulin, C.; Macro, M.; Caillot, D.; Chaleteix, C.; Roussel, M.; Garderet, L.; Royer, B.; Brechignac, S.; Tiab, M.; et al. VTD is superior to VCD prior to intensive therapy in multiple myeloma: Results of the prospective IFM2013-04 trial. Blood 2016, 127, 2569-2574. [CrossRef]

70. Roussel, M.; Lauwers-Cances, V.; Robillard, N.; Hulin, C.; Leleu, X.; Benboubker, L.; Marit, G.; Moreau, P.; Pegourie, B.; Caillot, D.; et al. Front-line transplantation program with lenalidomide, bortezomib, and dexamethasone combination as induction and consolidation followed by lenalidomide maintenance in patients with multiple myeloma: A phase II study by the Intergroupe Francophone du Myélome. J. Clin. Oncol. 2014, 32, 2712-2717.

71. Kumar, S.; Flinn, I.; Richardson, P.G.; Hari, P.; Callander, N.; Noga, S.J.; Stewart, A.K.; Turturro, F.; Rifkin, R.; Wolf, J.; et al. Randomized, multicenter, phase 2 study (EVOLUTION) of combinations of bortezomib, dexamethasone, cyclophosphamide, and lenalidomide in previously untreated multiple myeloma. Blood 2012, 119, 4375-4382. [CrossRef]

72. Pawlyn, C.; Davies, F.; Cairns, D.; Striha, A.; Hockaday, A.; Kishore, B.; Garg, M.; Williams, C.; Karunanithi7, K.; Lindsay, J.; et al. Quadruplet KCRD (Carfilzomib, Cyclophosphamide, Lenalidomide and Dexamethasone) Induction for Newly Diagnosed Myeloma Patients. In Proceedings of the International Myeloma Workshop, Boston, MA, USA, 12-15 September 2019; p. e2, [Abstract \#OAB-002]. Updated data presented at the meeting.

73. Jackson, G.H.; Davies, F.E.; Pawlyn, C.; Cairns, D.; Striha, A.; Hockaday, A.; Collett, C.; Jones, J.R.; Kishore, B.; Garg, M.; et al. A Quadruplet Regimen Comprising Carfilzomib, Cyclophosphamide, Lenalidomide, Dexamethasone (KCRD) Vs an Immunomodulatory Agent Containing Triplet (CTD/CRD) Induction Therapy Prior to Autologous Stem Cell Transplant: Results of the Myeloma XI Study. Blood 2018, 132, Abstract \#302 [ASH 2018 60th Meeting]. [CrossRef]

74. Attal, M.; Lauwers-Cances, V.; Hulin, C.; Leleu, X.; Caillot, D.; Escoffre, M.; Arnulf, B.; Macro, M.; Belhadj, K.; Garderet, L.; et al. Lenalidomide, Bortezomib, and Dexamethasone with Transplantation for Myeloma. N. Engl. J. Med. 2017, 376, 1311-1320. [CrossRef] [PubMed]

75. Rosinol, L.; Oriol, A.; Rios, R.; Sureda, A.; Blanchard, M.J.; Hernández, M.T.; Martínez-Martínez, R.; Moraleda, J.M.; Jarque, I.; Bargay, J.; et al. Bortezomib, Lenalidomide and Dexamethasone (VRD-GEM) As Induction Therapy Prior Autologous Stem Cell Transplantation (ASCT) in Multiple Myeloma (MM): Results of a Prospective Phase III Pethema/GEM Trial. Blood 2017, 130, Abstract \#2017 [ASH 2017 59th Annual Meeting]. [CrossRef]

76. Voorhees, P.; Kaufman, J.L.; Laubach, J.; Sborov, D.; Reeves, B.; Rodriguez, C.; Chari, A.; Silbermann, R.; Costa, L.; Anderson, L.; et al. Daratumumab + Lenalidomide, Bortezomib \& Dexamethasone Improves Depth of Response in Transplant-eligible Newly Diagnosed Multiple Myeloma: GRIFFIN. In Proceedings of the 17th International Myeloma Workshop, Boston, MA, USA, 12-15 Septemebr 2019; pp. 546-547; [Abstract \#OAB-87].

77. Moreau, P.; Attal, M.; Hulin, C.; Arnulf, B.; Belhadj, K.; Benboubker, L.; Béné, M.C.; Broijl, A.; Caillon, H.; Caillot, D.; et al. Bortezomib, thalidomide, and dexamethasone with or without daratumumab before and after autologous stem-cell transplantation for newly diagnosed multiple myeloma (CASSIOPEIA): A randomised, open-label, phase 3 study. Lancet 2019, 394, 29-38. [CrossRef]

78. Kumar, S.K.; Berdeja, J.G.; Niesvizky, R.; Lonial, S.; Laubach, J.P.; Hamadani, M.; Stewart, A.K.; Hari, P.; Roy, V.; Vescio, R.; et al. Ixazomib, lenalidomide, and dexamethasone in patients with newly diagnosed multiple myeloma: Long-term follow-up including ixazomib maintenance. Leukemia 2019, 33, 1736-1746. [CrossRef] [PubMed]

79. Rosiñol Dachs, L.; Hebraud, B.; Oriol, A.; Colin, A.-L.; Rios, R.; Hulin, C.; Blanchard, M.J.; Caillot, D.; Sureda, A.; Hernández, M.T.; et al. Integrated Analysis of Randomized Controlled Trials Evaluating Bortezomib + Lenalidomide + Dexamethasone or Bortezomib + Thalidomide + Dexamethasone Induction in Transplant-Eligible Newly Diagnosed Multiple Myeloma. Blood 2018, 132, Abstract \#3245 [ASH 2018 60th Meeting]. [CrossRef]

80. Palumbo, A.; Cavallo, F.; Gay, F.; Di Raimondo, F.; Ben Yehuda, D.; Petrucci, M.T.; Pezzatti, S.; Caravita, T.; Cerrato, C.; Ribakovsky, E.; et al. Autologous Transplantation and Maintenance Therapy in Multiple Myeloma. N. Engl. J. Med. 2014, 371, 895-905. [CrossRef] 
81. Cavo, M.; Hájek, R.; Pantani, L.; Beksac, M.; Oliva, S.; Dozza, L.; Johnsen, H.E.; Petrucci, M.T.; Mellqvist, U.-H.; Conticello, C.; et al. Autologous Stem Cell Transplantation Versus Bortezomib-Melphalan-Prednisone for Newly Diagnosed Multiple Myeloma: Second Interim Analysis of the Phase 3 EMN02/HO95 Study. Blood 2017, 130, Abstract \#397 [ASH 2017 59th Meeting]. [CrossRef]

82. Cavo, M.; Goldschmidt, H.; Rosinol, L.; Pantani, L.; Zweegman, S.; Salwender, H.J.; Lahuerta, J.J.; Lokhorst, H.M.; Petrucci, M.T.; Blau, I.; et al. Double Vs Single Autologous Stem Cell Transplantation for Newly Diagnosed Multiple Myeloma: Long-Term Follow-up (10-Years) Analysis of Randomized Phase 3 Studies. Blood 2018, 132, Abstract \#124 [ASH 2018 60th Meeting]. [CrossRef]

83. Stadtmauer, E.A.; Pasquini, M.C.; Blackwell, B.; Hari, P.; Bashey, A.; Devine, S.; Efebera, Y.; Ganguly, S.; Gasparetto, C.; Geller, N.; et al. Autologous transplantation, consolidation, and maintenance therapy in multiple myeloma: Results of the BMT CTN 0702 trial. J. Clin. Oncol. 2019, 37, 589-597. [CrossRef]

84. Sonneveld, P.; Beksac, M.; Van der Holt, B.; Dimopoulos, M.; Carella, A.; Ludwig, H.; Driessen, C.; Wester, R.; Hajek, R.; Cornelisse, P.; et al. Consolidation followed by maintenance vs maintenance alone in newly diagnosed, transplant eligible multiple myeloma: A randomized phase 3 study of the european myeloma network (emn02/ho95 mm trial). HemaSphere 2018, 2, 5-6.

85. McCarthy, P.L.; Holstein, S.A.; Petrucci, M.T.; Richardson, P.G.; Hulin, C.; Tosi, P.; Bringhen, S.; Musto, P.; Anderson, K.C.; Caillot, D.; et al. Lenalidomide Maintenance After Autologous Stem-Cell Transplantation in Newly Diagnosed Multiple Myeloma: A Meta-Analysis. J. Clin. Oncol. 2017, 35, 3279-3289. [CrossRef] [PubMed]

86. Jackson, G.H.; Davies, F.E.; Pawlyn, C.; Cairns, D.A.; Striha, A.; Collett, C.; Hockaday, A.; Jones, J.R.; Kishore, B.; Garg, M.; et al. Lenalidomide maintenance versus observation for patients with newly diagnosed multiple myeloma (Myeloma XI): A multicentre, open-label, randomised, phase 3 trial. Lancet Oncol. 2019, 20, 57-73. [CrossRef]

87. Oliva, S.; Gambella, M.; Larocca, A.; Spada, S.; Marzanati, E.; Mantoan, B.; Grammatico, S.; Conticello, C.; Gamberi, B.; Offidani, M.; et al. Prognostic Impact of Minimal Residual Disease By ASO-RQ-PCR in Multiple Myeloma: A Pooled Analysis of 2 Phase III Studies in Patients Treated with Lenalidomide after Front-Line Therapy. Blood 2016, 128, Abstract \#4409 [ASH 2016 58th Meeting]. [CrossRef]

88. Bonello, F.; Pulini, S.; Ballanti, S.; Gentile, M.; Spada, S.; Annibali, O.; Omedé, P.; Ronconi, S.; Cangialosi, C.; Podda, L.; et al. Lenalidomide Maintenance with or without Prednisone in Newly Diagnosed Myeloma Patients: A Pooled Analysis. Cancers 2019, 11, 1735. [CrossRef] [PubMed]

89. Mian, I.; Milton, D.R.; Shah, N.; Nieto, Y.; Popat, U.R.; Kebriaei, P.; Parmar, S.; Oran, B.; Shah, J.J.; Manasanch, E.E.; et al. Prolonged survival with a longer duration of maintenance lenalidomide after autologous hematopoietic stem cell transplantation for multiple myeloma. Cancer 2016, 122, 3831-3837. [CrossRef] [PubMed]

90. Sonneveld, P.; Avet-Loiseau, H.; Lonial, S.; Usmani, S.; Siegel, D.; Anderson, K.C.; Chng, W.-J.; Moreau, P.; Attal, M.; Kyle, R.A.; et al. Treatment of multiple myeloma with high-risk cytogenetics: A consensus of the International Myeloma Working Group. Blood 2016, 127, 2955-2962. [CrossRef]

91. Goldschmidt, H.; Lokhorst, H.M.; Mai, E.K.; van der Holt, B.; Blau, I.W.; Zweegman, S.; Weisel, K.C.; Vellenga, E.; Pfreundschuh, M.; Kersten, M.J.; et al. Bortezomib before and after high-dose therapy in myeloma: Long-term results from the phase III HOVON-65/GMMG-HD4 trial. Leukemia 2018, 32, 383-390. [CrossRef]

92. D'Agostino, M.; De Paoli, L.; Conticello, C.; Offidani, M.; Ria, R.; Petrucci, M.T.; Spada, S.; Marcatti, M.; Catalano, L.; Gilestro, M.; et al. Continuous therapy in standard- and high-risk newly-diagnosed multiple myeloma: A pooled analysis of 2 phase III trials. Crit. Rev. Oncol. Hematol. 2018, 132, 9-16. [CrossRef]

93. Gay, F.; Jackson, G.; Rosiñol, L.; Holstein, S.A.; Moreau, P.; Spada, S.; Davies, F.; Lahuerta, J.J.; Leleu, X.; Bringhen, S.; et al. Maintenance Treatment and Survival in Patients With Myeloma. JAMA Oncol. 2018, 4, 1389. [CrossRef]

94. D’Agostino, M.; Zaccaria, G.M.; Ziccheddu, B.; Genuardi, E.; Maura, F.; Oliva, S.; Auclair, D.; Yesil, J.; Capra, A.; Colucci, P.; et al. Clinical and Biological Early Relapse Predictors in Multiple Myeloma: An Analysis from the MMRF CoMMpass Study. In Proceedings of the 17 th International Myeloma Workshop, Boston, MA, USA, 12-15 September 2019; pp. 20-21; [Abstract \#OAB-018].

95. Dimopoulos, M.A.; Gay, F.; Schjesvold, F.; Beksac, M.; Hajek, R.; Weisel, K.C.; Goldschmidt, H.; Maisnar, V.; Moreau, P.; Min, C.K.; et al. Oral ixazomib maintenance following autologous stem cell transplantation 
(TOURMALINE-MM3): A double-blind, randomised, placebo-controlled phase 3 trial. Lancet 2019, 393, 253-264. [CrossRef]

96. Jakubowiak, A.J.; Dytfeld, D.; Griffith, K.A.; Lebovic, D.; Vesole, D.H.; Jagannath, S.; Al-Zoubi, A.; Anderson, T.; Nordgren, B.; Detweiler-Short, K.; et al. A phase 1/2 study of carfilzomib in combination with lenalidomide and low-dose dexamethasone as a frontline treatment for multiple myeloma. Blood 2012, 120, 1801-1809. [CrossRef] [PubMed]

97. Jakubowiak, A.; Raje, N.; Vij, R.; Reece, D.; Berdeja, J.; Vesole, D.; Jagannath, S.; Cole, C.; Faham, M.; Nam, J.; et al. Improved Efficacy After Incorporating Autologous Stem Cell Transplant (Asct) Into Krd Treatment With Carfilzomib (Cfz), Lenalidomide (Len), And Dexamethasone (Dex) In Newly Diagnosed Multiple Myeloma. Haematologica 2016, 101, 1-2.

98. Roussel, M.; Lauwers-Cances, V.; Robillard, N.; Belhadj, K.; Facon, T.; Garderet, L.; Escoffre, M.; Pegourie, B.; Benboubker, L.; Caillot, D.; et al. Frontline Therapy with Carfilzomib, Lenalidomide, and Dexamethasone (KRd) Induction Followed By Autologous Stem Cell Transplantation, Krd Consolidation and Lenalidomide Maintenance in Newly Diagnosed Multiple Myeloma (NDMM) Patients: Primary Results of th. Blood 2016, 128, Abstract \#1142 [ASH 2017 59th Meeting]. [CrossRef]

99. Gay, F.; Cerrato, C.; Scalabrini, D.R.; Galli, M.; Belotti, A.; Zamagni, E.; Ledda, A.; Grasso, M.; Angelucci, E.; Liberati, A.M.; et al. Carfilzomib-Lenalidomide-Dexamethasone (KRd) Induction-Autologous Transplant (ASCT)-Krd Consolidation Vs KRd 12 Cycles Vs Carfilzomib-Cyclophosphamide-Dexamethasone (KCd) Induction-ASCT-KCd Consolidation: Analysis of the Randomized FORTE Trial in Newly Di. Blood 2018, 132, Abstract \#121 [ASH 2018 60th Meeting]. [CrossRef]

100. Weisel, K.; Asemissen, A.M.; Schieferdecker, A.; Besemer, B.; Zago, M.; Mann, C.; Lutz, R.; Benner, A.; Tichy, D.; Bokemeyer, C.; et al. Isatuximab, Carfilzomib, Lenalidomide and Dexamethasone (I-KRd) in front-line treatment of high-risk Multiple Myeloma: Results of the Safety Run-In cohort in the phase II, multicenter GMMG-CONCEPT trial. In Proceedings of the International Myeloma Workshop, Boston, MA, USA, 12-15 September 2019; pp. 25-26; [Abstract \#OAB-023].

101. Bringhen, S.; D’Agostino, M.; Paris, L.; Ballanti, S.; Pescosta, N.; Spada, S.; Pezzatti, S.; Grasso, M.; Rota-Scalabrini, D.; De Rosa, L.; et al. Lenalidomide-based induction and maintenance in elderly newly diagnosed multiple myeloma patients: Updated results of the EMN01 randomized trial. Haematologica 2019. [ahead of print]. [CrossRef] [PubMed]

102. Salvini, M.; D'Agostino, M.; Bonello, F.; Boccadoro, M.; Bringhen, S. Determining treatment intensity in elderly patients with multiple myeloma. Expert Rev. Anticancer Ther. 2018, 18, 917-930. [CrossRef] [PubMed]

103. Palumbo, A.; Bringhen, S.; Mateos, M.-V.; Larocca, A.; Facon, T.; Kumar, S.; Offidani, M.; McCarthy, P.; Evangelista, A.; Lonial, S.; et al. Geriatric assessment predicts survival and toxicities in elderly myeloma patients: An International Myeloma Working Group report. Blood 2015, 125, 2068-2074. [CrossRef]

104. San Miguel, J.F.; Schlag, R.; Khuageva, N.K.; Dimopoulos, M.A.; Shpilberg, O.; Kropff, M.; Spicka, I.; Petrucci, M.T.; Palumbo, A.; Samoilova, O.S.; et al. Bortezomib plus Melphalan and Prednisone for Initial Treatment of Multiple Myeloma. N. Engl. J. Med. 2008, 359, 906-917. [CrossRef]

105. San Miguel, J.F.; Schlag, R.; Khuageva, N.K.; Dimopoulos, M.A.; Shpilberg, O.; Kropff, M.; Spicka, I.; Petrucci, M.T.; Palumbo, A.; Samoilova, O.S.; et al. Persistent Overall Survival Benefit and No Increased Risk of Second Malignancies With Bortezomib-Melphalan-Prednisone Versus Melphalan-Prednisone in Patients With Previously Untreated Multiple Myeloma. J. Clin. Oncol. 2013, 31, 448-455. [CrossRef]

106. Facon, T.; Dimopoulos, M.A.; Dispenzieri, A.; Catalano, J.V.; Belch, A.; Cavo, M.; Pinto, A.; Weisel, K.; Ludwig, H.; Bahlis, N.J.; et al. Final analysis of survival outcomes in the phase 3 FIRST trial of up-front treatment for multiple myeloma. Blood 2018, 131, 301-310. [CrossRef]

107. Larocca, A.; Salvini, M.; De Paoli, L.; Cascavilla, N.; Benevolo, G.; Galli, M.; Montefusco, V.; di Toritto, T.C.; Baraldi, A.; Spada, S.; et al. Efficacy and Feasibility of Dose/Schedule-Adjusted Rd-R Vs. Continuous Rd in Elderly and Intermediate-Fit Newly Diagnosed Multiple Myeloma (NDMM) Patients: RV-MM-PI-0752 Phase III Randomized Study. Blood 2018, 132, Abstract \#305 [ASH 2018 60th Meeting]. [CrossRef]

108. Durie, B.G.M.; Hoering, A.; Abidi, M.H.; Rajkumar, S.V.; Epstein, J.; Kahanic, S.P.; Thakuri, M.; Reu, F.; Reynolds, C.M.; Sexton, R.; et al. Bortezomib with lenalidomide and dexamethasone versus lenalidomide and dexamethasone alone in patients with newly diagnosed myeloma without intent for immediate autologous stem-cell transplant (SWOG S0777): A randomised, open-label, phase 3 trial. Lancet 2017, 389, 519-527. [CrossRef] 
109. O’Donnell, E.K.; Laubach, J.P.; Yee, A.J.; Chen, T.; Huff, C.A.; Basile, F.G.; Wade, P.M.; Paba-Prada, C.E.; Ghobrial, I.M.; Schlossman, R.L.; et al. A phase 2 study of modified lenalidomide, bortezomib and dexamethasone in transplant-ineligible multiple myeloma. Br. J. Haematol. 2018, 182, 222-230. [CrossRef] [PubMed]

110. Facon, T.; Kumar, S.; Plesner, T.; Orlowski, R.Z.; Moreau, P.; Bahlis, N.; Basu, S.; Nahi, H.; Hulin, C.; Quach, H.; et al. Daratumumab plus Lenalidomide and Dexamethasone for Untreated Myeloma. N. Engl. J. Med. 2019, 380, 2104-2115. [CrossRef] [PubMed]

111. Ocio, E.M.; Otero, P.R.; Bringhen, S.; Oliva, S.; Nogai, A.; Attal, M.; Moreau, P.; Kanagavel, D.; Fitzmaurice, T.; $\mathrm{Wu}$, J.; et al. Preliminary Results from a Phase I Study of Isatuximab (ISA) in Combination with Bortezomib, Lenalidomide, Dexamethasone (VRd) in Patients with Newly Diagnosed Multiple Myeloma (NDMM) Non-Eligible for Transplant. Blood 2018, 132, Abstract \#595 [ASH 2018 60th Meeting]. [CrossRef]

112. Moreau, P.; Kolb, B.; Attal, M.; Caillot, D.; Benboubker, L.; Tiab, M.; Touzeau, C.; Leleu, X.; Roussel, M.; Chaleteix, C.; et al. Phase 1/2 study of carfilzomib plus melphalan and prednisone in patients aged over 65 years with newly diagnosed multiple myeloma. Blood 2015, 125, 3100-3104. [CrossRef]

113. Facon, T.; Lee, J.H.; Moreau, P.; Niesvizky, R.; Dimopoulos, M.; Hajek, R.; Pour, L.; Jurczyszyn, A.; Qiu, L.; Klippel, Z.; et al. Carfilzomib or bortezomib with melphalan-prednisone for transplant-ineligible patients with newly diagnosed multiple myeloma. Blood 2019, 133, 1953-1963. [CrossRef]

114. Bringhen, S.; Petrucci, M.T.; Larocca, A.; Conticello, C.; Rossi, D.; Magarotto, V.; Musto, P.; Boccadifuoco, L.; Offidani, M.; Omede, P.; et al. Carfilzomib, cyclophosphamide, and dexamethasone in patients with newly diagnosed multiple myeloma: A multicenter, phase 2 study. Blood 2014, 124, 63-69. [CrossRef]

115. Bringhen, S.; D’Agostino, M.; De Paoli, L.; Montefusco, V.; Liberati, A.M.; Galieni, P.; Grammatico, S.; Muccio, V.E.; Esma, F.; De Angelis, C.; et al. Phase 1/2 study of weekly carfilzomib, cyclophosphamide, dexamethasone in newly diagnosed transplant-ineligible myeloma. Leukemia 2018, 32, 979-985. [CrossRef]

116. Bringhen, S.; Mina, R.; Petrucci, M.T.; Gaidano, G.; Ballanti, S.; Musto, P.; Offidani, M.; Spada, S.; Benevolo, G.; Ponticelli, E.; et al. Once-weekly versus twice-weekly carfilzomib in patients with newly diagnosed multiple myeloma: A pooled analysis of two phase I/II studies. Haematologica 2019, 104, 1640-1647. [CrossRef]

117. Palumbo, A.; Avet-Loiseau, H.; Oliva, S.; Lokhorst, H.M.; Goldschmidt, H.; Rosinol, L.; Richardson, P.; Caltagirone, S.; Lahuerta, J.J.; Facon, T.; et al. Revised International Staging System for Multiple Myeloma: A Report From International Myeloma Working Group. J. Clin. Oncol. 2015, 33, 2863-2869. [CrossRef] [PubMed]

118. Usmani, S.Z.; Heuck, C.; Mitchell, A.; Szymonifka, J.; Nair, B.; Hoering, A.; Alsayed, Y.; Waheed, S.; Haider, S.; Restrepo, A.; et al. Extramedullary disease portends poor prognosis in multiple myeloma and is over-represented in high-risk disease even in the era of novel agents. Haematologica 2012, 97, 1761-1767. [CrossRef] [PubMed]

119. Granell, M.; Calvo, X.; Garcia-Guiñón, A.; Escoda, L.; Abella, E.; Martínez, C.M.; Teixidó, M.; Gimenez, M.T.; Senín, A.; Sanz, P.; et al. Prognostic impact of circulating plasma cells in patients with multiple myeloma: Implications for plasma cell leukemia definition. Haematologica 2017, 102, 1099-1104. [CrossRef] [PubMed]

120. Sonneveld, P. Management of multiple myeloma in the relapsed/refractory patient. Hematology 2017, 2017, 508-517. [CrossRef] [PubMed]

121. Landgren, O.; Rustad, E.H. Meeting report: Advances in minimal residual disease testing in multiple myeloma 2018. Adv. Cell Gene Ther. 2019, 2, e26. [CrossRef]

122. Takamatsu, H.; Takezako, N.; Zheng, J.; Moorhead, M.; Carlton, V.E.H.; Kong, K.A.; Murata, R.; Ito, S.; Miyamoto, T.; Yokoyama, K.; et al. Prognostic value of sequencing-based minimal residual disease detection in patients with multiple myeloma who underwent autologous stem-cell transplantation. Ann. Oncol. 2017, 28, 2503-2510. [CrossRef]

123. Hahn, T.E.; Wallace, P.K.; Fraser, R.; Fei, M.; Tario, J.D.; Howard, A.; Zhang, Y.; Blackwell, B.; Brunstein, C.G.; Efebera, Y.A.; et al. Minimal Residual Disease (MRD) Assessment before and after Autologous Hematopoietic Cell Transplantation (AutoHCT) and Maintenance for Multiple Myeloma (MM): Results of the Prognostic Immunophenotyping for Myeloma Response (PRIMeR) Study. Biol. Blood Marrow Transplant. 2019, 25, S4-S6. [CrossRef] 
124. Paiva, B.; Vídriales, M.B.; Rosiñol, L.; Martínez-López, J.; Mateos, M.V.; Ocio, E.M.; Montalbán, M.A.; Cordón, L.; Gutiérrez, N.C.; Corchete, L.; et al. A multiparameter flow cytometry immunophenotypic algorithm for the identification of newly diagnosed symptomatic myeloma with an MGUS-like signature and long-term disease control. Leukemia 2013, 27, 2056-2061. [CrossRef] 